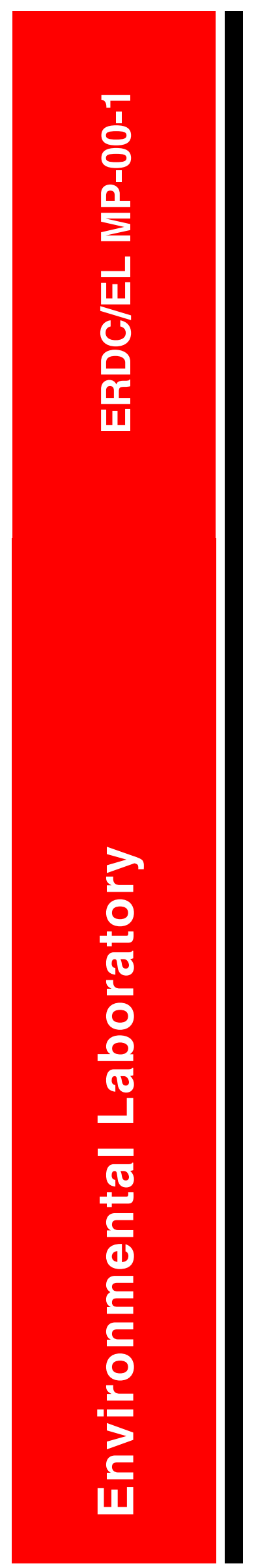

Aquatic Plant Control Research Program

Advantages and Disadvantages of Aquatic Plant Management Techniques

John D. Madsen

September 2000

Approved for public release; distribution is unlimited. 
The contents of this report are not to be used for advertising, publication, or promotional purposes. Citation of trade names does not constitute an official endorsement or approval of the use of such commercial products.

The findings of this report are not to be construed as an official Department of the Army position, unless so designated by other authorized documents. 


\title{
Advantages and Disadvantages of Aquatic Plant Management Techniques
}

by John D. Madsen

Environmental Laboratory

U.S. Army Engineer Research and Development Center 3909 Halls Ferry Road

Vicksburg, MS 39180-6199

Final report

Approved for public release; distribution is unlimited

\author{
Prepared for U.S. Army Corps of Engineers \\ Washington, DC 20314-1000 \\ and Aquatic Ecosystem Restoration Foundation \\ Lansing, MI 48917-4048
}




\section{Contents}

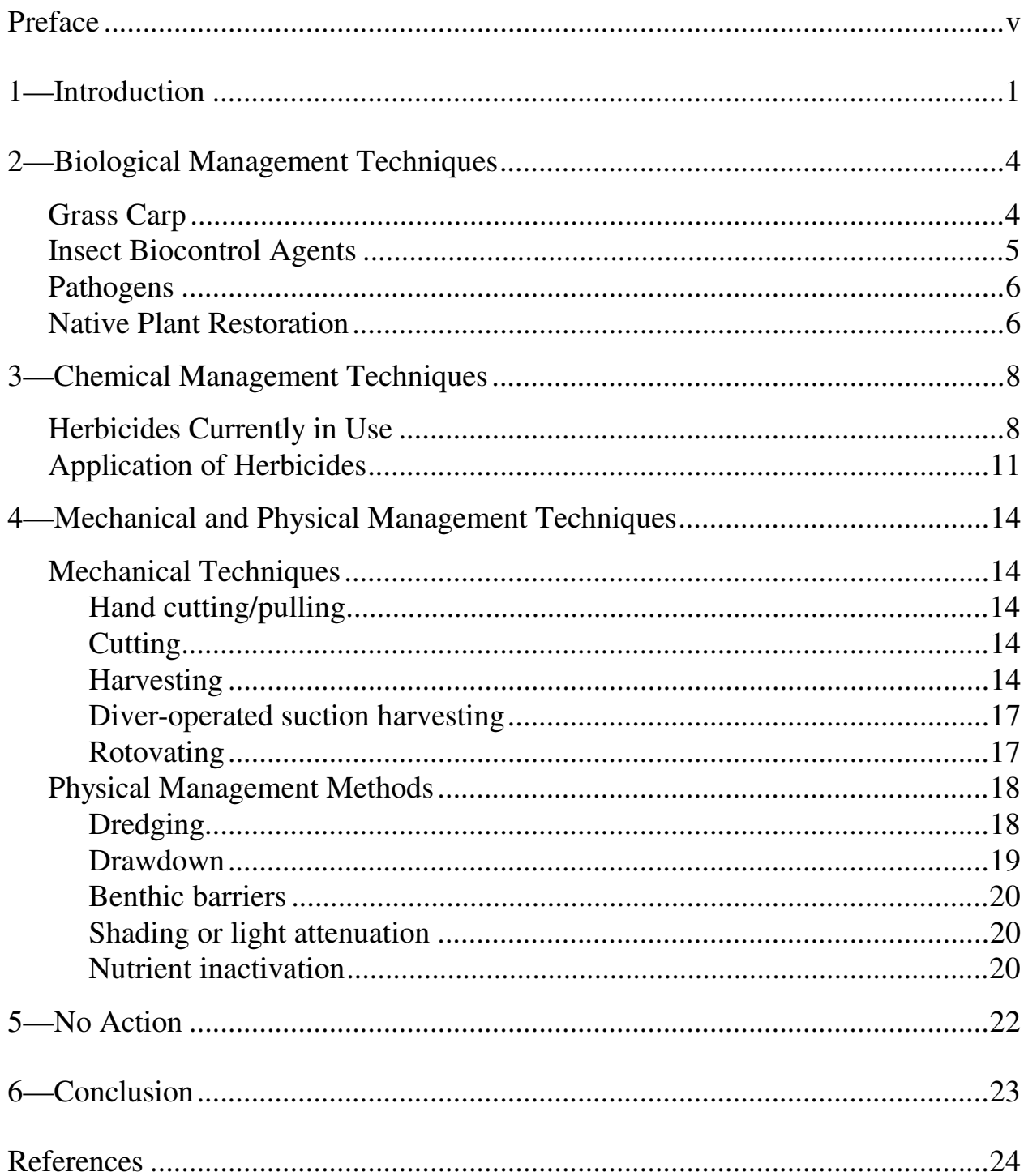

SF 298 


\section{List of Figures}

Figure 1. Author 1

Figure 2. Underwater view of the dense canopy formed by Eurasian watermilfoil (photo by author)...

Figure 3. An underwater view of a stand of diverse native aquatic plants (photo by author) 2

Figure 4. Preparing a tank mixture for an aquatic herbicide treatment 8

Figure 5. Divers returning to shore with hand-harvested Eurasian watermilfoil on Lake George, NY (photo by author).

Figure 6. Aquatic plant harvester in transit on Lake Minnetonka, MN (photo by author)

Figure 7. Aquamog configured as an underwater rotovator (photo by author) ..18

Figure 8. Author performing a quantitative evaluation of a plant community using underwater quadrats (photo by Dr. David L. Smith, Department of Biology, Le Moyne College, Syracuse, NY)

Figure 9. Aquatic plant restoration goal .23

\section{Figure of Tables}

Table 1. Useful Websites for Aquatic Plant Management Information ...............3

Table 2. Summary of Biological Management Methods for Aquatic Plants.......5

Table 3. Characteristics of U.S. Environmental Protection Agency-Approved

Aquatic Herbicides

Table 4. Application Restrictions of U.S. Environmental Protection Agency-

Approved Aquatic Herbicides

Table 5. Use Suggestions for U.S. Environmental Protection Agency-

Approved Aquatic Herbicides

Table 6. Characteristics of Mechanical Management Techniques

Table 7. Characteristics of Physical Management Techniques 


\section{Preface}

This report was originally published in the spring 2000 issue of LakeLine, Vol. 20, No. 1, pages 22-34. It is reprinted with permission from the publisher. The work reported herein was conducted under a Cooperative Research and Development Agreement between the Aquatic Ecosystem Restoration Foundation and the Environmental Laboratory (EL), Vicksburg, MS, U.S. Army Engineer Research and Development Center (ERDC), as part of the Aquatic Plant Control Research Program (APCRP). The APCRP is sponsored by Headquarters, U.S. Army Corps of Engineers (HQUSACE), and is assigned to ERDC under the purview of EL. Funding was provided under Department of the Army Appropriation 96X3122, Construction General. The APCRP is managed under the Center for Aquatic Plant Research and Technology (CAPRT), Dr. John W. Barko, EL, Director. Mr. Robert C. Gunkel, Jr., EL, was Associate Director for the CAPRT. Program Monitor during this study was Mr. Timothy R. Toplisek, HQUSACE.

This report was prepared by Dr. John D. Madsen, then with Ecosystem Processes and Effects Branch (EPEB), Environmental Processes and Effects Division (EPED), Environmental Laboratory (EL), Vicksburg, MS, U.S. Army Engineer Research and Development Center (ERDC). Dr. Madsen is now with the Biological Sciences Department, Minnesota State University, Mankato. The work was conducted under the general supervision of Dr. Robert Kennedy, Acting Chief, EPEB; Dr. Richard E. Price, Chief, EPED; and Dr. John W. Keeley, Acting Director, EL.

At the time of publication of this report, Dr. James R. Houston was Director of ERDC, and COL James S. Weller, EN, was Commander.

This report should be cited as follows:

Madsen, J. D. (2000). "Advantages and disadvantages of aquatic plant management techniques," ERDC/EL MP-00-1, U.S. Army Engineer Research and Development Center, Vicksburg, MS.

The contents of this report are not to be used for advertising, publication, or promotional purposes. Citation of trade names does not constitute an official endorsement or approval for the use of such commercial products. 


\section{Introduction}

As I work on aquatic plant management research projects around the United States (Figure 1), the most frequent statement I hear is: "I hope you can figure out some way of getting rid of these weeds" (Figure 2). When I was younger (and more patient), I would explain many of the available options. After a few years, I realized that the major obstacles to effective management of aquatic plants were sociological rather than scientific. In most instances, a motivated

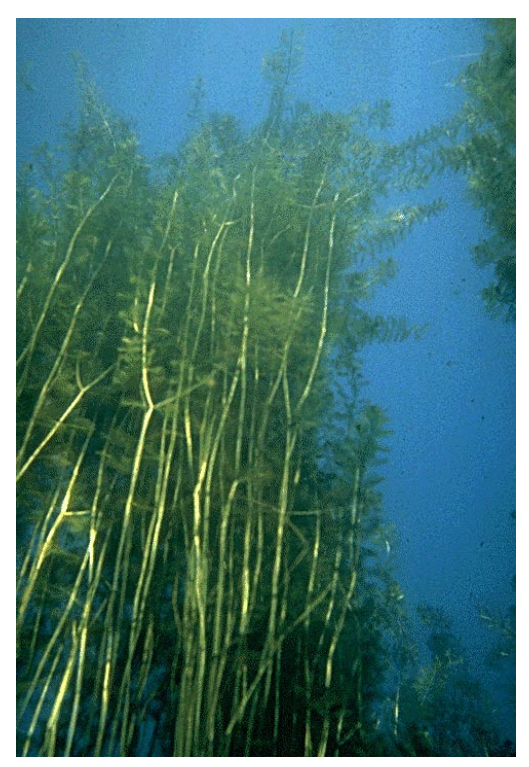
resource management group (whether they be a lake association or a local, regional, state or federal agency) could use a half-dozen of the available options to manage aquatic plants in

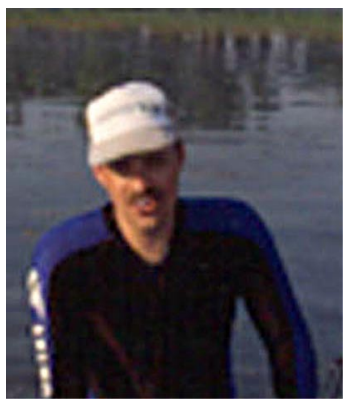

Figure 1. Author their lake. The limitations to effective management are time, patience, and funds, not the lack of an effective management tool.

All aquatic plant management techniques have positive and negative attributes. None of the techniques is without some adverse environmental impact; all have both strengths and weaknesses. In selecting management techniques, selections need to be based on economic, environmental, and technical constraints.

Management decisions should be made on a sitespecific basis (Madsen 1997). Management techniques should be considered on their technical merits. A truly

Figure 2. Underwater view of the dense canopy formed by Eurasian watermilfoil (photo by author) integrated aquatic plant management approach will vary the use of techniques both spatially and temporally. Spatial variation in technique selection should be based on site use intensity and economic, environmental and technical constraints.

Management should be tailored to the priority and goals of each site. All areas within the lake should be categorized as to use, restrictions, and priority. Based on these categories, management techniques can be selected. For instance, swimming beaches and boat launches are high-use areas, and should have a high priority. Wildlife areas (e.g., refuges) have lower intensity use, and some restrictions to management. Based on these categories, management techniques can be selected. The high-priority, high-intensity use sites might justify high-cost management techniques such as benthic barriers or diver-operated suction harvesting. Low-intensity use areas might either remain untreated if resources are 
low, or would be categorized for less expensive techniques such as herbicides. Likewise, areas with higher concentrations of plants should receive more resources than areas with no plants or with acceptable levels of infestation. Helsel (2000) provides more detail about selecting the proper level of management through the preparation of an aquatic plant management and protection plan.

As dense colonies are brought under control (Figure 3), maintenance management approaches can be used (Deschenes and Ludlow 1993). After a target plant species has entered a system, continuous management will be required. However, under no circumstances should management be discontinued once plant densities are low. If management techniques are very successful, management may entail only monitoring the system and hand-removing individuals that are occasionally found. Scale the control technique to the level of infestation, the priority of the site, the use, and the availability of resources.

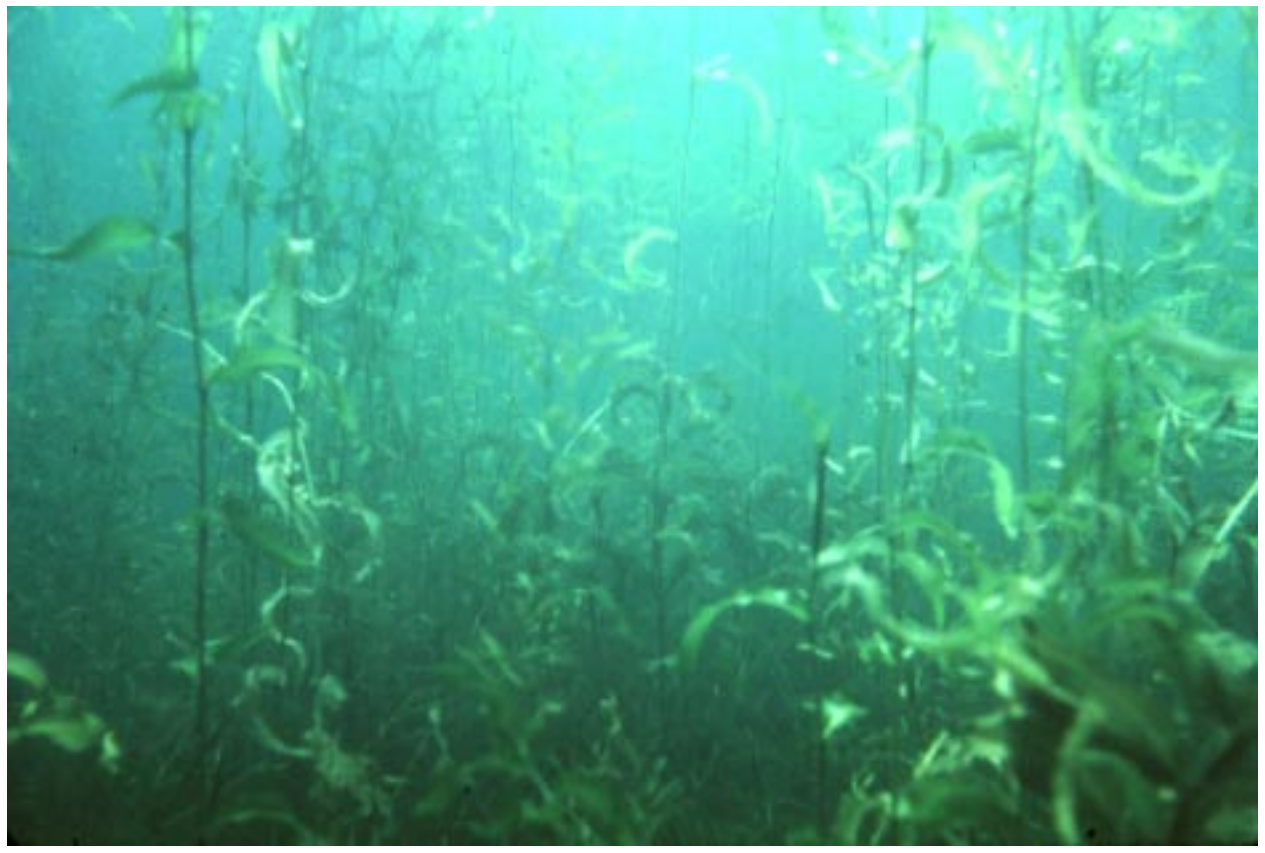

Figure 3. An underwater view of a stand of diverse native aquatic plants (photo by author)

Several useful computer programs and other useful information systems are currently available on a CD-ROM as the Aquatic Plant Information System (APIS). Some helpful websites are listed in Table 1. Another excellent source of information on target and nontarget plants and their management is the Aquatic Plant Information Retrieval System, operated by the University of Florida's Center for Aquatic Plants. In addition to free bibliographic searches, the Center has a variety of educational materials available. 


\begin{tabular}{|c|c|}
\hline \multicolumn{2}{|c|}{$\begin{array}{l}\text { Table } 1 \\
\text { Useful Websites for Aquatic Plant Management Information }\end{array}$} \\
\hline $\begin{array}{l}\text { Federal Government } \\
\text { Aquatic Plant Control Research Program } \\
\text { USACE Aquatic Plant Control Operations } \\
\text { Support Center } \\
\text { USGS Nonindigenous Aquatic Species }\end{array}$ & $\begin{array}{l}\text { www.wes.army.mil/el/aqua } \\
\text { www.saj.usace.army.mil/conops/apc/apc_page.htm/ } \\
\text { http://nas.er.usgs.gov/ }\end{array}$ \\
\hline $\begin{array}{l}\text { State Government } \\
\text { Washington State Department of Ecology }\end{array}$ & www.ecy.wa.gov \\
\hline $\begin{array}{l}\text { University } \\
\text { University of Florida Center for Aquatic and } \\
\text { Invasive Plants }\end{array}$ & http://aquat1.ifas.ufl.edu/ \\
\hline $\begin{array}{l}\text { Professional Society } \\
\text { Aquatic Plant Management Society } \\
\text { North American Lake Management Society }\end{array}$ & $\begin{array}{l}\text { www.apms.org } \\
\text { www.nalms.org }\end{array}$ \\
\hline $\begin{array}{l}\text { Foundations } \\
\text { Aquatic Ecosystem Restoration Foundation }\end{array}$ & www.aquatics.org \\
\hline
\end{tabular}

One important rule to remember is that no management technique is intrinsically superior to another, nor will one management technique (e.g., a single chemical, or herbicides as a group) be sufficient for all situations in a management program. Rather, all techniques should be considered tools in the manager's toolbox. Some are more expensive but will better control dense populations in larger areas. For small nuisance plant populations $(<0.1$ acre, 0.03 hectare) or new colonies, hand picking may actually be the best approach. Each site should be evaluated and management techniques selected based on the desired level of control and environmental and economic constraints. 


\section{Biological Management Techniques}

Many exotic and native organisms have been used for biological control programs (Gallagher and Haller 1990); however, current operational or research and development efforts center on a few: grass carp (or white amur, Ctenopharyngodon idella) and introduced insects for hydrilla, naturalized pathogens for Eurasian watermilfoil and hydrilla, and naturalized insects for Eurasian watermilfoil (Table 2).

\section{Grass Carp}

Grass carp, a popular control agent for aquatic plants especially in small ponds or isolated bodies of water, are particularly effective in controlling hydrilla. These fish have strong feeding preferences (Pine and Anderson 1991) and will selectively feed on plants in a mixed community from the most to the least preferred. If hydrilla is the target plant, this may be beneficial--at least until the hydrilla is eaten (Van Dyke et al. 1984). If Eurasian watermilfoil is the target, all other plants may be eaten first, and grass carp may in fact never completely remove Eurasian watermilfoil (Fowler and Robson 1978). In addition, there are many concerns about using grass carp, including the length of time they remain in the system, the difficulty of controlling where and what they eat, the highly variable results for large systems (>500 acres), the escape of carp from the managed system, the impact of their feeding on nontarget plant and animal species, and the difficulty of removing them when control is no longer needed (Bonar et al. 1993).

An initial concern regarding reproduction of grass carp (Stanley et al. 1978; Webb et al. 1994) has been addressed largely through the use of sterile triploids (Durocher 1994). The effectiveness of grass carp is strongly influenced by water temperature and seasonality, with northern ecosystems typically requiring substantially higher stocking rates than southern ones (Stewart and Boyd 1994). In addition, stocking rates can vary by an order of magnitude, depending on whether adequate results are required in 3 years as opposed to the need for more immediate results (Stewart and Boyd 1994). The problem of lag time can be moderated by combining stocking of grass carp with herbicide treatments in the first year (Eggeman 1994). However, a strong tendency for obtaining either no perceived control with understocking or complete plant elimination with overstocking remains--it has been termed the "all-or-none" dilemma (Haller 


\section{Table 2}

Summary of Biological Management Methods for Aquatic Plants

\begin{tabular}{|c|c|c|c|c|c|}
\hline $\begin{array}{l}\text { Management } \\
\text { Method }\end{array}$ & Description & Advantages & Disadvantages & $\begin{array}{l}\text { Systems Where } \\
\text { Used Effectively }\end{array}$ & $\begin{array}{l}\text { Plant Species } \\
\text { Response }\end{array}$ \\
\hline $\begin{array}{l}\text { Grass Carp / } \\
\text { White Amur }\end{array}$ & Herbivorous fish & $\begin{array}{l}\text { Long-term } \\
\text { (decades), } \\
\text { relatively } \\
\text { inexpensive }\end{array}$ & $\begin{array}{l}\text { Cannot control } \\
\text { feeding sites, } \\
\text { difficult to contain } \\
\text { in water body, } \\
\text { tendency for "all or } \\
\text { none" community } \\
\text { response, } \\
\text { persistent }\end{array}$ & $\begin{array}{l}\text { Isolated water } \\
\text { bodies, effective } \\
\text { against hydrilla } \\
\text { and other } \\
\text { preferred species. } \\
\text { (Operational) }\end{array}$ & $\begin{array}{l}\text { Fish have strong } \\
\text { preference for } \\
\text { hydrilla and some } \\
\text { native plants, } \\
\text { avoid Eurasian } \\
\text { watermilfoil, } \\
\text { generally do not } \\
\text { prefer floating } \\
\text { plants }\end{array}$ \\
\hline Neochetina spp. & $\begin{array}{l}\text { Waterhyacinth } \\
\text { weevils }\end{array}$ & Species selective & $\begin{array}{l}\text { Not effective in } \\
\text { reducing areal } \\
\text { coverage in many } \\
\text { situations }\end{array}$ & $\begin{array}{l}\text { Released in } \\
\text { Florida, Gulf Coast } \\
\text { states. } \\
\text { (Developmental) }\end{array}$ & $\begin{array}{l}\text { Leaf scars, some } \\
\text { reduction in } \\
\text { growth }\end{array}$ \\
\hline $\begin{array}{l}\text { Hydrellia spp. } \\
\text { Bagous spp. }\end{array}$ & $\begin{array}{l}\text { Hydrilla fly, hydrilla } \\
\text { stem weevil }\end{array}$ & Species selective & $\begin{array}{l}\text { Has not yet been } \\
\text { established }\end{array}$ & $\begin{array}{l}\text { Released in } \\
\text { Florida, Alabama, } \\
\text { Texas. } \\
\text { (Research) }\end{array}$ & Limited \\
\hline $\begin{array}{l}\text { Euhrychiopsis } \\
\text { lecontei and other } \\
\text { native insects }\end{array}$ & $\begin{array}{l}\text { Weevil - native or } \\
\text { naturalized }\end{array}$ & $\begin{array}{l}\text { Already } \\
\text { established in U.S. }\end{array}$ & $\begin{array}{l}\text { Less selective, } \\
\text { currently under } \\
\text { R\&D }\end{array}$ & $\begin{array}{l}\text { Currently under } \\
\text { study in Vermont, } \\
\text { Minnesota } \\
\text { (Research) }\end{array}$ & $\begin{array}{l}\text { Plants loose } \\
\text { buoyancy, weevil } \\
\text { interferes with } \\
\text { transfer of } \\
\text { carbohydrates }\end{array}$ \\
\hline $\begin{array}{l}\text { Mycoleptodiscus } \\
\text { terrestris (Mt) }\end{array}$ & $\begin{array}{l}\text { Fungal pathogen; } \\
\text { acts as a contact } \\
\text { bioherbicide }\end{array}$ & $\begin{array}{l}\text { Low dispersion, } \\
\text { fairly broad } \\
\text { spectrum }\end{array}$ & $\begin{array}{l}\text { Expense, cross- } \\
\text { contamination, } \\
\text { inconsistent } \\
\text { viability and } \\
\text { virulence of } \\
\text { formulation }\end{array}$ & $\begin{array}{l}\text { Under R\&D for } \\
\text { both Eurasian } \\
\text { watermilfoil and } \\
\text { hydrilla }\end{array}$ & $\begin{array}{l}\text { "Contact } \\
\text { Bioherbicide," } \\
\text { plants rapidly fall } \\
\text { apart, but regrow } \\
\text { from roots }\end{array}$ \\
\hline $\begin{array}{l}\text { Native Plant } \\
\text { Community } \\
\text { Restoration }\end{array}$ & $\begin{array}{l}\text { Planting of } \\
\text { desirable native } \\
\text { plant species or } \\
\text { community }\end{array}$ & $\begin{array}{l}\text { Provides habitat, } \\
\text { may slow } \\
\text { reinvasion or initial } \\
\text { invasion }\end{array}$ & $\begin{array}{l}\text { Expensive, } \\
\text { techniques still } \\
\text { under } \\
\text { development }\end{array}$ & $\begin{array}{l}\text { Under R\&D } \\
\text { around the country }\end{array}$ & $\begin{array}{l}\text { Native plants } \\
\text { provide ecosystem } \\
\text { benefits, slow } \\
\text { invasion }\end{array}$ \\
\hline
\end{tabular}

1994). If achieving an intermediate density of plants is even possible using grass carp, it is certainly very difficult and must be based on a more sophisticated understanding of interacting factors than have been considered in the past.

\section{Insect Biocontrol Agents}

Insect biocontrol agents currently under research and development for hydrilla were discovered from overseas investigations of native habitats and brought in through the biocontrol "pipeline" (Cofrancesco 1994). Hydrilla biocontrol agents include the flies Hydrellia pakistanae and H. balciunasi (Buckingham and Okrah 1993) and the weevils Bagous hydrillae and B. affinis (Grodowitz et al. 1995).

Although several introduced biocontrol agents feed in a complementary fashion to 
stress hydrilla populations, it is too early in the research and development process to predict operational-scale success. For instance, mathematical models of $H$. pakistanae growth rates suggest that even if the fly were successful in central Florida, its development rate may be too slow in the colder climate of northern Alabama to be effective (Boyd and Stewart 1994).

Although foreign surveys for biocontrol agents for Eurasian watermilfoil have been recently initiated (Buckingham 1995), most effort has been spent looking at naturalized or native insects that feed on this species (Kangasniemi 1983). In particular, laboratory, mesocosm, and field research have been vigorously pursued on the pyralid moth Acentria nivea (Creed and Sheldon 1994) and on the weevil, Euhrychiopsis lecontei (Creed and Sheldon 1993, 1994; Newman and Maher 1995). Euhrychiopsis lecontei looks promising in that it is capable of cutting off the flow of carbohydrates to root crowns, reducing the plant's ability to store carbohydrates for over wintering (Newman et al. 1996) and reducing the buoyancy of the canopy (Creed et al. 1992). However, an effective strategy for large-scale applications using these naturalized insects at an operational level has yet to be verified.

\section{Pathogens}

Pathogens, like insects, are usually discovered by searching overseas for pathogens in the native range of the target plant. Despite overseas searches (Harvey et al. 1995), no foreign pathogen agents are currently under development. Actually, the best potential pathogen control agent for submersed aquatic plants appears to be an endemic species, Mycoleptodiscus terrestris (Mt) (Shearer 1995). Small-scale field tests indicated that Mt was an effective mycoherbicide, and acted like a contact herbicide with little spread or drift (Shearer 1995). In addition, Mt has shown promise in the laboratory as part of an integrated management strategy in which applications of Mt combined with low dosage rates of the herbicide fluridone act synergistically (Nelson et al. 1998). However, more research and development effort must be accomplished before an effective marketable mycoherbicide is available for use.

\section{Native Plant Restoration}

The last type of biological management technique, native plant restoration, is an ecological approach to managing for a desired plant community. The basic idea is that restoring a native plant community should be the end goal of most aquatic plant management programs (Nichols 1991; Smart and Doyle 1995). Lakes currently lacking a native plant community can have these communities established (Smart et al. 1996a,b). Extant native plant communities should be protected from invasion by nonnative species through mechanisms detailed later. In communities that have only recently been invaded by nonnative species, a propagule bank probably exists that will restore the native community after management of the nonnative plant (Getsinger et al. 1997). However, in communities that have had monospecific nonnative plant dominance for a long 
period of time (e.g., greater than 10 years), native plants may have to be reintroduced after a successful maintenance management program has been instituted. A healthy native plant community might slow invasion or reinvasion by nonnative species and will provide the environmental and habitat needs of an aquatic littoral zone. However, even healthy, well-developed native plant communities may eventually be invaded and dominated by nonnative species (Madsen et al. 1991). 


\section{Chemical Management Techniques}

In many ways, chemical management techniques have changed dramatically in the past 20 years. Increased concern about the safety of pesticide use in the 1960s and 1970s changed the review process for all pesticides, particularly for products used in water (Figure 4). Currently, no product can be labeled for aquatic use if it poses more than a one in a million chance of causing significant damage to human health, the environment, or wildlife resources. In addition, it may not show evidence of biomagnification, bioavailability, or persistence in the environment (Joyce 1991).

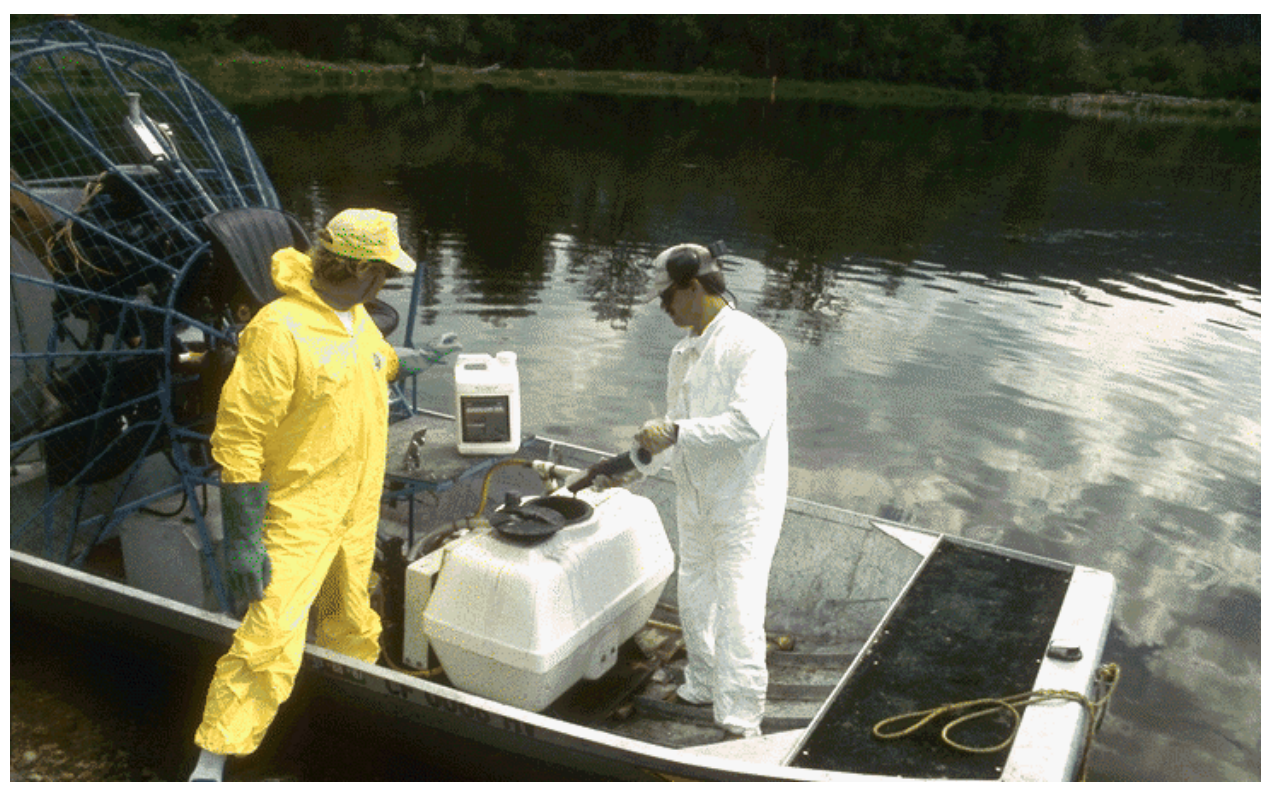

Figure 4. Preparing a tank mixture for an aquatic herbicide treatment

\section{Herbicides Currently in Use}

The greatest change for herbicides came with the passage of the Federal Insecticide, Fungicide and Rodenticide Act (FIFRA) first passed in 1972 and amended in 1988 (Getsinger 1991; Nesheim 1993). Due to more stringent and costly standards for testing, fewer compounds are now available for aquatic use. 
In 1976, 20 active ingredients were available; as of 1995, only six are available (Table 3), with one additional compound (triclopyr) undergoing the registration process.

\begin{tabular}{|c|c|c|c|c|c|}
\hline Compound & Trade Name & Company & $\begin{array}{l}\text { Formulation } \\
\text { Contact vs. } \\
\text { Systemic }\end{array}$ & Mode of Action & $\begin{array}{l}\text { Bluegill } 96 \mathrm{hr} \\
\mathrm{LC}_{50}, \mathrm{mg} / \mathrm{L}\end{array}$ \\
\hline $\begin{array}{l}\text { Complexed } \\
\text { Copper }^{1}\end{array}$ & $\begin{array}{l}\text { Cutrine-Plus } \\
\text { Komeen } \\
\text { Koplex } \\
\text { K-Tea }\end{array}$ & $\begin{array}{l}\text { Applied } \\
\text { Biochemists } \\
\text { (Cutrine) } \\
\text { Griffin Corporation }\end{array}$ & $\begin{array}{l}\text { Various } \\
\text { complexing agents } \\
\text { with copper, } \\
\text { superior to } \mathrm{CuSO}_{4} \\
\text { Systemic }\end{array}$ & Plant cell toxicant & 1250 \\
\hline $2,4-D^{1}$ & $\begin{array}{l}\text { Aqua-Kleen } \\
\text { Weedar-64 } \\
\text { Wee-Rhap A-6D } \\
\text { Several Others }\end{array}$ & $\begin{array}{l}\text { Applied } \\
\text { Biochemists } \\
\text { Rhone-Poulenc } \\
\text { Inter-Ag }\end{array}$ & $\begin{array}{l}\text { BEE salt } \\
\text { DMA liquid } \\
\text { IEE liquid } \\
\text { Systemic }\end{array}$ & $\begin{array}{l}\text { Selective plant- } \\
\text { growth regulator }\end{array}$ & $\begin{array}{l}1.1-1.3 \\
123-230\end{array}$ \\
\hline Diquat $^{1}$ & Reward & Zeneca & $\begin{array}{l}\text { Liquid } \\
\text { Contact }\end{array}$ & $\begin{array}{l}\text { Disrupts plant cell } \\
\text { membrane } \\
\text { integrity }\end{array}$ & $10-140$ \\
\hline Endothall $^{1}$ & $\begin{array}{l}\text { Aquathol K } \\
\text { Hydrothal } 191 \\
\text { Aquathol granular }\end{array}$ & $\begin{array}{l}\text { Elf Atochem (All } \\
\text { Formulations) }\end{array}$ & $\begin{array}{l}\text { Liquid or granular } \\
\text { Contact }\end{array}$ & $\begin{array}{l}\text { Inactivates plant } \\
\text { protein synthesis }\end{array}$ & $\begin{array}{l}125 \\
0.06-0.2\end{array}$ \\
\hline Fluridone $^{1}$ & $\begin{array}{l}\text { Sonar AS } \\
\text { Sonar SRP }\end{array}$ & SePRO & $\begin{array}{l}\text { Liquid or granular } \\
\text { Systemic }\end{array}$ & $\begin{array}{l}\text { Disrupts } \\
\text { carotenoid } \\
\text { synthesis, causing } \\
\text { bleaching of } \\
\text { chlorophyll }\end{array}$ & $9-12.5$ \\
\hline Glyphosate $^{1}$ & Rodeo & Monsanto & Liquid Systemic & $\begin{array}{l}\text { Disrupts synthesis } \\
\text { of phenylalanine }\end{array}$ & $4.2-14$ \\
\hline $\begin{array}{l}\text { Triclopyr }{ }^{2} \text { (EUP } \\
\text { Only) }\end{array}$ & $\begin{array}{l}\text { Garlon 3A (EUP) } \\
\text { Renovate (EUP) }\end{array}$ & SePRO & Liquid Systemic & $\begin{array}{l}\text { Selective plant } \\
\text { growth regulator }\end{array}$ & 148 \\
\hline
\end{tabular}

However, the compounds no longer registered for aquatic use are not necessarily too dangerous; rather, in most cases, the companies marketing them opted not to pursue registration due to economic reasons. Their reluctance to invest in registration is understandable--it can take \$20-40 million and 8-12 years to navigate successfully the registration process and its accompanying series of laboratory and field testing, with no guarantee for return on investment (Getsinger 1991). What remains are six active ingredients that not only are ensured safe for aquatic use (when used according to the label) but also have manufacturers committed to the aquatic market. 
The important caveat to remember is that these products are safe when used according to the label. The U.S. Environmental Protection Agency (EPA) approved label provides guidelines protecting the health of the environment, the humans using that environment, and the applicators of the herbicide. In most states, there are additional permitting or regulatory restrictions on the use of these herbicides. A typical state restriction requires that these herbicides may be applied only by licensed applicators. Annual updates from state regulatory and environmental agencies are necessary to check for changes in label restrictions and application policies or permit requirements before developing or implementing any plans for applying herbicides.

Herbicides labeled for aquatic use can be classified as either contact or systemic. Contact herbicides act immediately on the tissues contacted, typically causing extensive cellular damage at the point of uptake but not affecting areas untouched by the herbicide. Typically, these herbicides are faster acting, but they do not have a sustained effect, in many cases not killing root crowns, roots, or rhizomes. In contrast, systemic herbicides are translocated throughout the plant. They are slower acting but often result in mortality of the entire plant.

Complexed copper compounds include a variety of formulations from different companies, under different names and labels, in which copper is chelated in an organic complexing agent that keeps it in solution. Formerly, copper sulfate was used in applications, predominantly for the control of phytoplankton. However, the copper rapidly precipitated, especially in harder water, and was no longer available, leading to the production of complexed copper agents. Complexed copper is very effective for algal control, somewhat effective for several vascular plants (particularly hydrilla), and is also used in tank mixes with diquat to increase its effectiveness.

A widely used aquatic herbicide for many broadleaf species, such as Eurasian watermilfoil, is 2,4-D. A selective systemic herbicide, it effectively controls broadleaf plants with a relatively short contact time, but does not generally harm the pondweeds or water celery. However, it is also not effective against elodea or hydrilla.

Diquat is a contact herbicide that will act on a very short contact time. It causes a rapid die-off of the shoot portions of the plant it contacts, but is not effective on roots, rhizomes or tubers, requiring subsequent applications. Diquat will bind to particulate and dissolved organic matter, which restricts its use in some water bodies. It is also effective in a tank mix with copper compounds.

Endothall is another contact herbicide. Unlike diquat, it is not affected by particulates or dissolved organic material. It should not be used in tank mixtures with copper, as it can have an antagonistic reaction with chelated copper compounds.

Fluridone is a nonselective systemic aquatic herbicide. It requires very long exposure times but may be effective at very low concentrations. Fluridone is widely used for both hydrilla and Eurasian watermilfoil management. It appears 
to work best where the entire lake or flowage system can be managed, but not in spot treatments or high water exchange areas.

Glyphosate is not effective on submersed plants, and triclopyr is not yet labeled for general aquatic use, so neither compound will receive additional attention.

\section{Application of Herbicides}

In treating submersed species, the applicator is actually treating the water with a herbicide, and allowing the plant to take up herbicide from the water. This creates a situation in which the applicator needs to know the exchange rate of the water to have a successful application (Getsinger et al. 1991). The exposure time of the plant to the herbicide is determined predominantly by the water exchange rate. The response of different plant species to different herbicides is a function of the properties of both the plant and the herbicide. The applicator also needs to match a herbicide with an appropriate concentration and exposure-time relationship for the target species (Netherland 1991). The concentration and exposuretime relationship for a given compound have been determined from laboratory experiments. For instance, if it is known from water exchange studies that the exposure time will ensure only 24 hours of contact with $1 \mathrm{mg} /$ liter of 2,4-D if applied at full label rate, than a 75 percent control rate for Eurasian watermilfoil can be expected. If longer exposure times are expected, than lower concentrations can be applied. One goal of this area of research is to allow for lower application rates, both to save money on herbicides and to introduce a lower total amount of herbicide into the aquatic environment. For higher exchange rates, the applicator will have to use higher concentrations of the contact herbicides such as diquat or endothall; slower exchange rates may allow the use of systemic herbicides (Tables 3 and 4). However, some systems are limited in selecting herbicides for use, because it is never admissible to use concentrations of herbicides higher than the allowed EPA maximum label rate.

Some herbicides (e.g., 2,4-D and triclopyr) are intrinsically selective, being very effective for controlling broadleaf plants such as Eurasian watermilfoil but not narrow-leaved plants or grasses such as hydrilla (Table 5). Other herbicides may be used selectively but only through application based on the target and nontarget plant's biology. Recent research has shown fluridone may be used to selectively manage Eurasian watermilfoil and hydrilla at extremely low (e.g., 5 to $8 \mathrm{ppb}$ ) concentrations; however, concentrations must be carefully monitored to avoid failure to control the target species (Getsinger 1998; Netherland et al. 1997).

The future of herbicide use may include applying plant growth regulators (PGR's), such as flurprimidol and paclobutrazol, which reduce plant elongation rather than cause plant death (Van 1988). The future of this approach dimmed considerably in the U.S. when Du Pont Corporation did not pursue the registration of bensulfuron methyl, which showed great promise in restricting tuber formation in hydrilla (Haller et al. 1992) and PGR activity in Eurasian watermilfoil (Getsinger et al. 1994). 


\begin{tabular}{|c|c|c|c|c|c|c|}
\hline Compound & $\begin{array}{l}\text { Persistence } \\
\text { (half-life, days) }\end{array}$ & $\begin{array}{l}\text { Maximum } \\
\text { Application } \\
\text { Rate }\end{array}$ & $\begin{array}{l}\text { Maximum } \\
\text { Water } \\
\text { Concentration } \\
\text { mg/L }\end{array}$ & Safety Factor & $\begin{array}{l}\text { Application } \\
\text { Notes }\end{array}$ & $\begin{array}{l}\text { Recommended by } \\
\text { Environmental } \\
\text { Laboratory }\end{array}$ \\
\hline $\begin{array}{l}\text { Complexed } \\
\text { Copper }^{1}\end{array}$ & 3 & $1.5 \mathrm{gal} / \mathrm{ft} / \mathrm{acre}$ & 1.0 & $>50$ & $\begin{array}{l}\text { Algicide / } \\
\text { Herbicide }\end{array}$ & $\begin{array}{l}\text { Hydrilla, other } \\
\text { submersed spp. }\end{array}$ \\
\hline $2,4-D^{1}$ & 7.5 & $0.5 \mathrm{gal} / \mathrm{acre}$ & 2.0 & $>25$ & $\begin{array}{l}\text { Some } \\
\text { formulations for } \\
\text { special permits } \\
\text { only }\end{array}$ & $\begin{array}{l}\text { Eurasian watermilfoil, } \\
\text { water hyacinth, and } \\
\text { others }\end{array}$ \\
\hline Diquat $^{1}$ & $1-7$ & $2 \mathrm{gal} / \mathrm{acre}$ & 2 & 5 & $\begin{array}{l}\text { Binds with } \\
\text { particles } \\
\text { (suspended } \\
\text { solids) in water }\end{array}$ & All \\
\hline Endothall ${ }^{1}$ & $4-7$ & $13 \mathrm{gal} / \mathrm{acre}$ & 5.0 & $\begin{array}{l}>10 \text { (Aquathol) } \\
<1.0 \text { (Hydrothal) }\end{array}$ & $\begin{array}{l}\text { Fish are } \\
\text { sensitive to } \\
\text { Hydrothal } 191 \text { - } \\
\text { over } 1 \mathrm{mg} / \mathrm{L} \\
\text { may cause fish } \\
\text { kill }\end{array}$ & All submersed spp. \\
\hline Fluridone $^{1}$ & 21 & $1.1 \mathrm{qt} / \mathrm{acre}$ & $\begin{array}{l}0.15 \\
(150 \mathrm{ppb})\end{array}$ & $>20$ & $\begin{array}{l}\text { Applications } \\
\text { have been } \\
\text { successful } \\
\text { below } 10 \mathrm{ppb}\end{array}$ & $\begin{array}{l}\text { Most submersed } \\
\text { spp. }\end{array}$ \\
\hline Glyphosate $^{1}$ & 14 & $2 \mathrm{gal} / \mathrm{acre}$ & 0.2 & $>20$ & $\begin{array}{l}\text { Aerial portions } \\
\text { only - not for } \\
\text { submersed } \\
\text { plants }\end{array}$ & $\begin{array}{l}\text { Most emergent and } \\
\text { floating spp. }\end{array}$ \\
\hline $\begin{array}{l}\text { Triclopyr } \\
\text { (EUP Only) }\end{array}$ & na & na & 2.5 & $>50$ & $\begin{array}{l}\text { EUP/Special } \\
\text { Needs only - US } \\
\text { EPA label } \\
\text { expected in } \\
2000\end{array}$ & $\begin{array}{l}\text { Eurasian watermilfoil, } \\
\text { water hyacinth, } \\
\text { others }\end{array}$ \\
\hline
\end{tabular}

A second area in the future of herbicide use is integrated control, where herbicides are used in conjunction with other management techniques to improve their effectiveness. Herbicides have been used with grass carp (Eggeman 1994), insect biocontrol agents (Haag and Habeck 1991; Van 1988), and pathogens (Nelson et al. 1998; Sorsa et al. 1988) to increase their effectiveness. Combining herbicides with mechanical and physical control techniques is also possible. 


\begin{tabular}{|c|c|c|c|c|c|}
\hline Compound & $\begin{array}{l}\text { Exposure Time } \\
\text { (Water) }\end{array}$ & Advantages & Disadvantages & $\begin{array}{l}\text { Systems Where } \\
\text { Used Effectively }\end{array}$ & $\begin{array}{l}\text { Plant Species } \\
\text { Response }\end{array}$ \\
\hline $\begin{array}{l}\text { Complexed } \\
\text { Copper }^{1}\end{array}$ & $\begin{array}{l}\text { Intermediate (18- } \\
72 \text { hours) }\end{array}$ & $\begin{array}{l}\text { Inexpensive, rapid } \\
\text { action, approved for } \\
\text { drinking water }\end{array}$ & $\begin{array}{l}\text { Does not } \\
\text { biodegrade, but } \\
\text { biologically inactive } \\
\text { in sediments }\end{array}$ & $\begin{array}{l}\text { Lakes as algicide, } \\
\text { herbicide in higher } \\
\text { exchange areas }\end{array}$ & $\begin{array}{l}\text { Broad-spectrum, } \\
\text { acts in } 7-10 \text { days or } \\
\text { up to } 4-6 \text { weeks }\end{array}$ \\
\hline $2,4-D^{1}$ & $\begin{array}{l}\text { Intermediate (18- } \\
72 \text { hours) }\end{array}$ & $\begin{array}{l}\text { Inexpensive, } \\
\text { systemic }\end{array}$ & Public perception & $\begin{array}{l}\text { Water hyacinth and } \\
\text { Eurasian watermilfoil } \\
\text { control, lakes and } \\
\text { slow-flow areas, } \\
\text { purple loosestrife }\end{array}$ & $\begin{array}{l}\text { Selective to broad- } \\
\text { leaves, acts in 5-7 } \\
\text { days up to } 2 \text { weeks }\end{array}$ \\
\hline Diquat $^{1}$ & $\begin{array}{l}\text { Short (12-36 } \\
\text { hours) }\end{array}$ & $\begin{array}{l}\text { Rapid action, limited } \\
\text { drift }\end{array}$ & $\begin{array}{l}\text { Does not affect } \\
\text { underground } \\
\text { portions }\end{array}$ & $\begin{array}{l}\text { Shoreline, localized } \\
\text { treatments, higher } \\
\text { exchange rate areas }\end{array}$ & $\begin{array}{l}\text { Broad-spectrum, } \\
\text { acts in } 7 \text { days }\end{array}$ \\
\hline Endothall $^{1}$ & $\begin{array}{l}\text { Short (12-36 } \\
\text { hours) }\end{array}$ & $\begin{array}{l}\text { Rapid action, limited } \\
\text { drift }\end{array}$ & $\begin{array}{l}\text { Does not affect } \\
\text { underground } \\
\text { portions }\end{array}$ & $\begin{array}{l}\text { Shoreline, localized } \\
\text { treatments, higher } \\
\text { exchange rate areas }\end{array}$ & $\begin{array}{l}\text { Broad spectrum, } \\
\text { acts in 7-14 days }\end{array}$ \\
\hline Fluridone $^{1}$ & $\begin{array}{l}\text { Very long (30-60 } \\
\text { days) }\end{array}$ & $\begin{array}{l}\text { Very low dosage } \\
\text { required, few label } \\
\text { restrictions, systemic }\end{array}$ & $\begin{array}{l}\text { Very long contact } \\
\text { period }\end{array}$ & $\begin{array}{l}\text { Small lakes, slow- } \\
\text { flowing systems }\end{array}$ & $\begin{array}{l}\text { Broad spectrum, } \\
\text { acts in } 30-90 \text { days }\end{array}$ \\
\hline Glyphosate $^{1}$ & Not Applicable & $\begin{array}{l}\text { Widely used, few } \\
\text { label restrictions, } \\
\text { systemic }\end{array}$ & $\begin{array}{l}\text { Very slow action, no } \\
\text { submersed control }\end{array}$ & $\begin{array}{l}\text { Nature preserves } \\
\text { and refuges; } \\
\text { emergent and } \\
\text { floating-leaved } \\
\text { plants only }\end{array}$ & $\begin{array}{l}\text { Broad spectrum, } \\
\text { acts in } 7-10 \text { days, up } \\
\text { to } 4 \text { weeks }\end{array}$ \\
\hline $\begin{array}{l}\text { Triclopyr }^{2} \\
\text { (EUP Only) }\end{array}$ & $\begin{array}{l}\text { Intermediate (12- } \\
60 \text { hours) }\end{array}$ & Selective, systemic & $\begin{array}{l}\text { Not currently labeled } \\
\text { for general aquatic } \\
\text { use }\end{array}$ & $\begin{array}{l}\text { Lakes and slow-flow } \\
\text { areas, purple } \\
\text { loosestrife }\end{array}$ & $\begin{array}{l}\text { Selective to broad- } \\
\text { leaves, acts in } 5-7 \\
\text { days, up to } 2 \text { weeks }\end{array}$ \\
\hline
\end{tabular}




\section{Mechanical and Physical Management Techniques}

\section{Mechanical Techniques}

Mechanical management methods have been widespread in attempts to control aquatic plants (Table 6). Yet all too often the approach to a solution is strictly "engineering," rather than applying engineering to a knowledge of biology and ecology of the target organism. Likewise, the erstwhile inventor often neglects a concern for the environmental implications of use of the mechanical control, confirmed in the belief that it must be better than "using poisons."

\section{Hand cutting/pulling}

The most common form of mechanical control is actually the use of hand cutters, rakes, or bare hands (no tools) to remove vegetation (Figure 5). Not only is this the most common method worldwide, but also it is the most widely used method by most lakeshore owners in the U.S. In a do-it-yourself guide, McComas (1993) listed a large number of hand implements and other small-scale devices for mechanical control. These techniques are most appropriate for localized nuisance problems of both nonindigenous and native plants.

\section{Cutting}

Larger scale control efforts require more mechanization (Table 6). The first uses a mechanical cutter, which is typically a boat with a sickle-bar cutting blade. Although cutting alone is relatively rapid, it leaves large mats of plants that can not only spread the plant but also create a floating obstacle, wash up on shorelines, and cause water quality problems through decomposition. Because of these problems, cutting operations are typically combined with plant removal. However, in some applications, removal is not necessary, in which case cutting alone is sufficient.

\section{Harvesting}

In mechanical harvesting, cutting operations are combined with plant removal (Figure 6). Occasionally, there are separate cutting and harvesting boats. More 


\section{Table 6 Characteristics of Mechanical Management Techniques}

\begin{tabular}{|c|c|c|c|c|c|}
\hline $\begin{array}{l}\text { Management } \\
\text { Method }\end{array}$ & Description & Advantages & Disadvantages & $\begin{array}{l}\text { Systems Where } \\
\text { Used Effectively }\end{array}$ & $\begin{array}{l}\text { Plant Species } \\
\text { Response }\end{array}$ \\
\hline $\begin{array}{l}\text { Hand- cutting/ } \\
\text { pulling }\end{array}$ & $\begin{array}{l}\text { Direct hand pulling } \\
\text { or use of hand } \\
\text { tools }\end{array}$ & $\begin{array}{l}\text { Low-technology, } \\
\text { affordable, can be } \\
\text { selective }\end{array}$ & $\begin{array}{l}\text { Labor-intensive, } \\
\text { cost is labor-based }\end{array}$ & $\begin{array}{l}\text { Most of the } \\
\text { undeveloped } \\
\text { world, volunteer } \\
\text { labor pools }\end{array}$ & $\begin{array}{l}\text { Very effective in } \\
\text { very localized } \\
\text { areas }\end{array}$ \\
\hline Cutting & $\begin{array}{l}\text { Cut weeds with } \\
\text { mechanical device } \\
\text { (typically boat- } \\
\text { mounted sickle } \\
\text { bar) without } \\
\text { collection }\end{array}$ & $\begin{array}{l}\text { More rapid than } \\
\text { harvesting }\end{array}$ & $\begin{array}{l}\text { Large mats of cut } \\
\text { weeds may } \\
\text { become a health } \\
\text { and environmental } \\
\text { problem, may } \\
\text { spread infestation }\end{array}$ & $\begin{array}{l}\text { Heavily infested } \\
\text { systems }\end{array}$ & $\begin{array}{l}\text { Nonselective, } \\
\text { short-term }\end{array}$ \\
\hline $\begin{array}{l}\text { Harvesting (cut } \\
\text { and remove) }\end{array}$ & $\begin{array}{l}\text { Mechanical cutting } \\
\text { with plant removal }\end{array}$ & $\begin{array}{l}\text { Removes plant } \\
\text { biomass }\end{array}$ & $\begin{array}{l}\text { Slower and more } \\
\text { expensive than } \\
\text { cutting; } \\
\text { resuspension of } \\
\text { sediments }\end{array}$ & $\begin{array}{l}\text { Widespread use } \\
\text { with chronic plant } \\
\text { problems }\end{array}$ & $\begin{array}{l}\text { Like cutting, it is } \\
\text { cosmetic, } \\
\text { nonselective short- } \\
\text { term }\end{array}$ \\
\hline $\begin{array}{l}\text { Grinder or "Juicer" } \\
\text { (cut and grind) }\end{array}$ & $\begin{array}{l}\text { Mechanical cutting } \\
\text { with grinding of } \\
\text { plant material and } \\
\text { in-lake disposal }\end{array}$ & $\begin{array}{l}\text { Immediate relief of } \\
\text { plant nuisance, no } \\
\text { disposal }\end{array}$ & $\begin{array}{l}\text { Resuspension of } \\
\text { sediments, } \\
\text { decomposition of } \\
\text { plants in lake, } \\
\text { floating plant } \\
\text { material }\end{array}$ & $\begin{array}{l}\text { Useful for chronic } \\
\text { plant problems } \\
\text { where disposal of } \\
\text { plants is } \\
\text { problematic }\end{array}$ & $\begin{array}{l}\text { Like cutting and } \\
\text { harvesting, it is } \\
\text { cosmetic, } \\
\text { nonselective, } \\
\text { short-term }\end{array}$ \\
\hline $\begin{array}{l}\text { Diver-operated } \\
\text { suction harvester }\end{array}$ & $\begin{array}{l}\text { Vacuum lift used to } \\
\text { remove plant } \\
\text { stems, roots, } \\
\text { leaves, sediment } \\
\text { left in place }\end{array}$ & $\begin{array}{l}\text { Moderately } \\
\text { selective (based } \\
\text { on visibility and } \\
\text { operator), longer } \\
\text { term }\end{array}$ & $\begin{array}{l}\text { Slow and cost- } \\
\text { intensive }\end{array}$ & $\begin{array}{l}\text { Useful for smaller } \\
\text { nuisance plant } \\
\text { populations in } \\
\text { which plant density } \\
\text { is moderate }\end{array}$ & $\begin{array}{l}\text { Typically have } \\
\text { minimal regrowth } \\
\text { for Eurasian } \\
\text { watermilfoil; not } \\
\text { effective for tuber- } \\
\text { setting hydrilla }\end{array}$ \\
\hline Rotovating & $\begin{array}{l}\text { Cultivator on long } \\
\text { arm for tilling } \\
\text { aquatic sediments }\end{array}$ & $\begin{array}{l}\text { Disrupts Eurasian } \\
\text { watermilfoil stem } \\
\text { bases, } \\
\text { intermediate-term } \\
\text { results }\end{array}$ & $\begin{array}{l}\text { May spread large } \\
\text { numbers of } \\
\text { fragments; } \\
\text { resuspension of } \\
\text { sediments }\end{array}$ & $\begin{array}{l}\text { Used extensively in } \\
\text { the Pacific } \\
\text { Northwest and } \\
\text { British Columbia, } \\
\text { with mixed results }\end{array}$ & $\begin{array}{l}\text { Effective in } \\
\text { disrupting Eurasian } \\
\text { watermilfoil dense } \\
\text { stands; not } \\
\text { selective and only } \\
\text { intermediate-term }\end{array}$ \\
\hline
\end{tabular}

often, the harvesters have both a sickle-bar cutting blade with a conveyor belt that loads the cut material on a boat. Disposal vehicles carry the plant material away.

One neglected aspect of harvesting operations is disposal of plant material. The plant material is generally more than 90 percent water and not suitable as a feed and cannot be sold or made into anything truly useful. The common response is to use it as mulch. Due to the disposal problem, some recent machine designs have included a shredder, chopper, or grinder to dispose of the plant material back into the lake. Although some concern has been expressed about the release of nutrients, the actual amount of nutrients released is small relative to other sources. A more realistic concern, at least in southern water bodies, is the attraction of large carnivores (e.g., alligators) to the "chum" resulting from chopped fish and other organisms that are a "by-catch." 


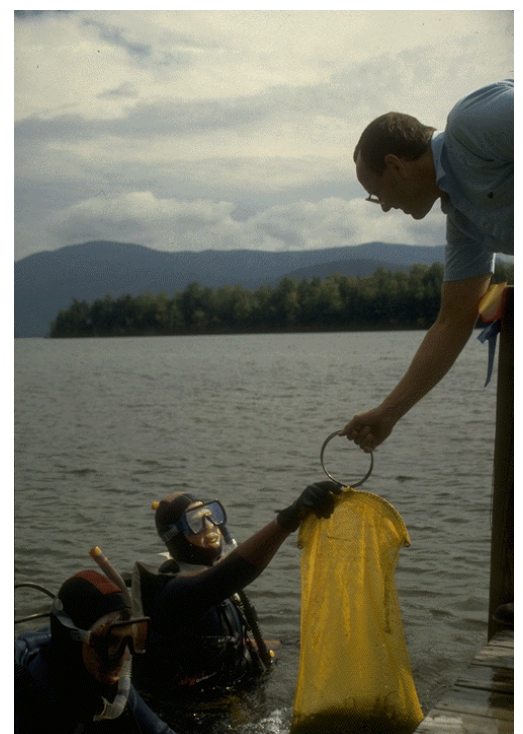

Figure 5. Divers returning to shore with handharvested Eurasian watermilfoil on Lake George, NY (photo by author)

Several studies have indicated that one harvest per year provides only brief control, whereas two to three harvests of the same plot in a given year are required to provide adequate annual control. However, cutting three times in a year may also reduce growth the following year (Madsen et al. 1988; Nichols and Cottam 1972). Most researchers directly ascribed successful control to reductions in total stored carbohydrates (Kimbel and Carpenter 1981).

Although many claim that harvesting is environmentally superior to herbicide use, most neglect to consider that harvesting removes large numbers of macroinvertebrates, semi-aquatic vertebrates, forage fishes, young-of-the-year fishes, and even adult gamefishes (Engel 1990). The harvester acts as a large, nonselective predator "grazing" in the littoral zone. In addition, harvesting can resuspend bottom sediments into the water column, releasing nutrients and other accumulated compounds.

However, not all secondary effects of harvesting are negative. Removal of large amounts of plants can improve the diel oxygen balance of littoral zones and rivers, particularly in shallower water (Carpenter and Gasith 1978; Madsen et al. 1988). At this point, no studies have indicated whether native communities respond preferentially to harvesting.

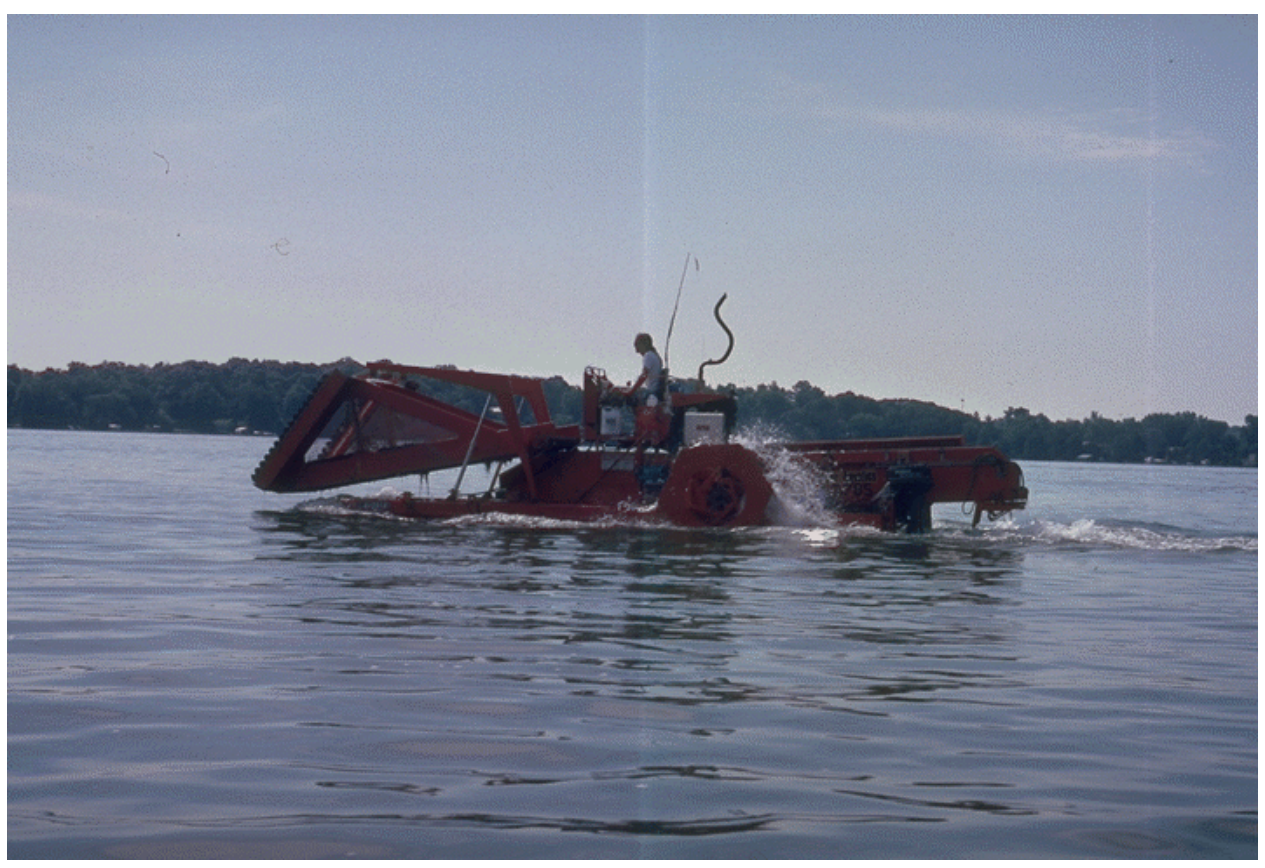

Figure 6. Aquatic plant harvester in transit on Lake Minnetonka, MN (photo by author) 
In the past, harvesting was widely touted as a mechanism to remove nutrients from lake systems. However, ecosystem studies indicated that harvesting was not likely to significantly improve the trophic status of a lake. For instance, harvesting all available plants in Lake Wingra, Wisconsin, removed only 16 percent of the nitrogen and 37 percent of the phosphorus net influxes into the lake; these removals were insignificant compared to the lake's internal pools of those nutrients (Carpenter and Adams 1976, 1978). Plant harvesting in Southern Chemung Lake, Ontario, removed 20 percent of the annual net phosphorus input (Wile 1975). In a more eutrophic system (Sallie Lake, Minnesota), continuous harvesting of aquatic plants in the littoral zone during summer removed only 1.4 percent of the total phosphorus input (Peterson et al. 1974). In a less eutrophic system (East Twin Lake, Ohio), harvesting the entire littoral zone would have removed from 26 to 44 percent of the phosphorus and from 92 to 100 percent of the nitrogen net loadings to the lake over a 5-year study period (Conyers and Cooke 1983).

Harvesting aquatic plants is not an effective tool for reducing nutrient loads in a lake; in none of the above scenarios was the internal nutrient pool reduced. In the best-case scenario, removing all the plants in the lake only kept pace with the amount of external nitrogen loading and with not quite half of the external phosphorus loading. Because no operational control program is going to remove all plants in the littoral zone, it is unlikely that any operational harvesting program will significantly impact the internal nutrient balance of the system.

\section{Diver-operated suction harvesting}

The use of diver-operated suction harvesting (or dredging, as it is often called) is a fairly recent technique. The technique is called "harvesting" rather than "dredging" because, although a specialized small-scale dredge is used, sediments are not removed from the system. Sediments are resuspended during the operation, but using a sediment curtain mitigates these effects. Divers use this device to remove plants from the sediment (NYSDEC and FOLA 1990). The technique can be very selective; divers can literally choose the plants to be removed. Removal is efficient and regrowth is limited. The system is very slow $\left(100 \mathrm{~m}^{2}\right.$ per person-day; Eichler et al. 1993), and disposal of plant material must also be resolved. However, it is an excellent method for small beds of plants or areas of scattered clumps of plants too large for hand harvesting.

\section{Rotovating}

The last major mechanical management technique is rotovating (Figure 7), which is widely used in the Pacific Northwest and formerly in British Columbia for management of Eurasian watermilfoil. This method uses rotovator heads on submersible arms to till up the bottom sediments and to destroy the root crowns. Rotovating is relatively rapid and can effectively control dense beds of Eurasian watermilfoil for up to 2 years (Gibbons and Gibbons 1988). However, it spreads Eurasian watermilfoil fragments, resuspends large amounts of sediments and nutrients, causes high levels of turbidity, disrupts benthic communities, and is nonselective. 


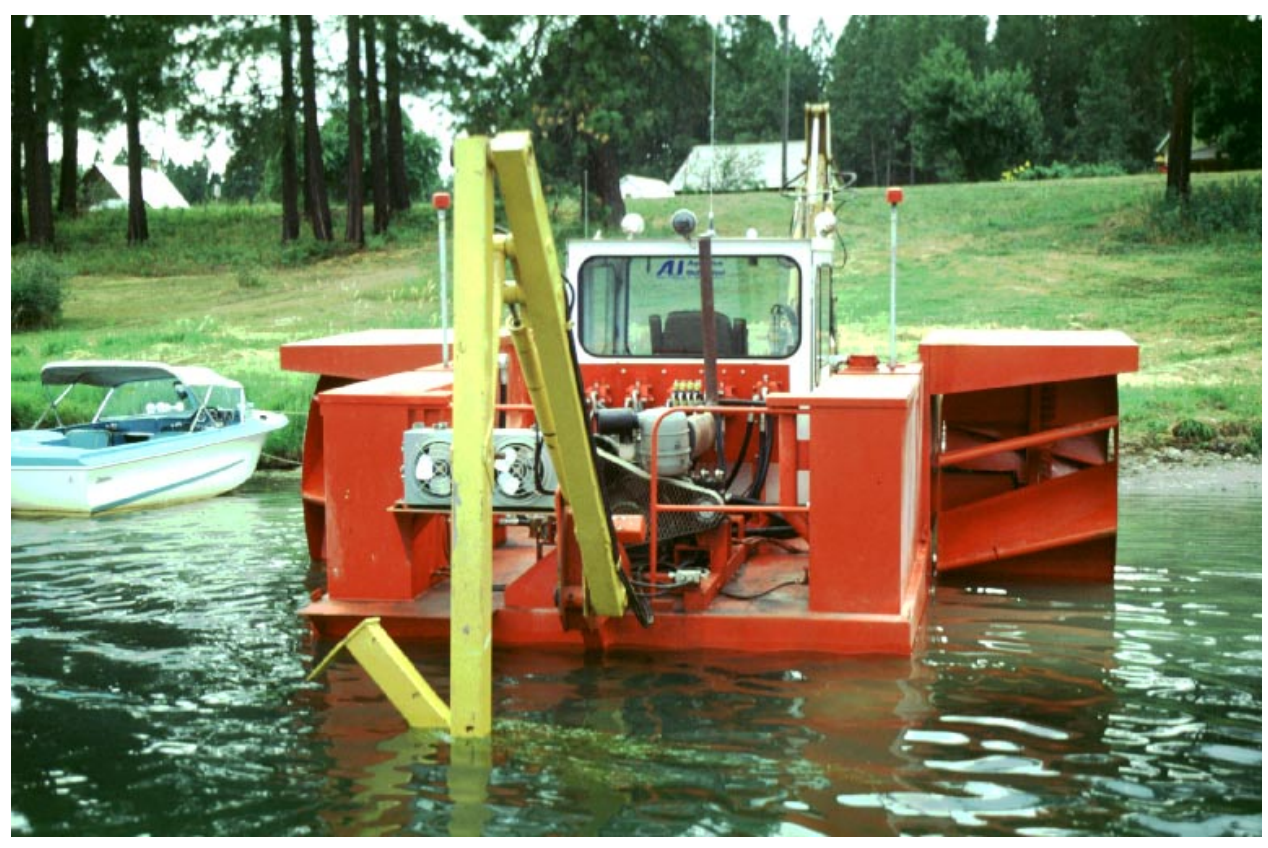

Figure 7. Aquamog configured as an underwater rotovator (photo by author)

\section{Physical Management Methods}

Physical management methods may or may not utilize large equipment but are distinguished from mechanical techniques in the following manner: in mechanical techniques the machines act directly upon the plants; in physical techniques the environment of the plants is manipulated, which in turn acts upon the plants. Several physical techniques are commonly used: dredging, drawdown, benthic barriers, shading or light attenuation, and nutrient inactivation (Table 7).

\section{Dredging}

Dredging is usually not performed solely for aquatic plant management but to restore lakes that have been filled in with sediments, have excess nutrients, have inadequate pelagic and hypolimnetic zones, need deepening, or require removal of toxic substances (Peterson 1982). However, lakes that are very shallow due to sedimentation typically have excess plant growth. This method is effective in that dredging typically forms an area of the lake too deep for plants to grow, thus opening an area for riparian use (Nichols 1984). By opening more diverse habitats and creating depth gradients, dredging may also create more diversity in the plant community (Nichols 1984). Results of dredging can be very long term. Biomass of Potamogeton crispus in Collins Lake, New York, remained significantly lower than pre-dredging levels 10 years after dredging (Tobiessen et al. 1992). Due to the cost, environmental impacts, and the problem of disposal, dredging should not be performed for aquatic plant management alone. It is best used as a multipurpose lake remediation technique. 


\begin{tabular}{|c|c|c|c|c|c|}
\hline $\begin{array}{l}\text { Management } \\
\text { Method }\end{array}$ & Description & Advantages & Disadvantages & $\begin{array}{l}\text { Systems Where } \\
\text { Used Effectively }\end{array}$ & $\begin{array}{l}\text { Plant Species } \\
\text { Response }\end{array}$ \\
\hline $\begin{array}{l}\text { Dredging/ } \\
\text { Sediment } \\
\text { Removal }\end{array}$ & $\begin{array}{l}\text { Use mechanical } \\
\text { sediment dredge } \\
\text { to remove } \\
\text { sediments, } \\
\text { deepen water }\end{array}$ & $\begin{array}{l}\text { Creates deeper } \\
\text { water, very long- } \\
\text { term results }\end{array}$ & $\begin{array}{l}\text { Very expensive, } \\
\text { must deal with } \\
\text { dredge sediment }\end{array}$ & $\begin{array}{l}\text { Shallow ponds } \\
\text { and lakes, } \\
\text { particularly those } \\
\text { filled in by } \\
\text { sedimentation }\end{array}$ & $\begin{array}{l}\text { Often creates } \\
\text { large usable areas } \\
\text { of lake, not } \\
\text { selective }\end{array}$ \\
\hline Drawdown & $\begin{array}{l}\text { "De-water" a lake } \\
\text { or river for an } \\
\text { extended period of } \\
\text { time }\end{array}$ & $\begin{array}{l}\text { Inexpensive, very } \\
\text { effective, } \\
\text { moderate-term }\end{array}$ & $\begin{array}{l}\text { Can have severe } \\
\text { environmental } \\
\text { impacts, severe } \\
\text { recreational/ } \\
\text { riparian user } \\
\text { effects }\end{array}$ & $\begin{array}{l}\text { Only useful for } \\
\text { man-made lakes } \\
\text { or regulated rivers } \\
\text { with a dam or } \\
\text { water control } \\
\text { structure }\end{array}$ & $\begin{array}{l}\text { Selective based } \\
\text { on perennation } \\
\text { strategy; effective } \\
\text { on evergreen } \\
\text { perennials, less } \\
\text { effective on } \\
\text { herbaceous } \\
\text { perennials }\end{array}$ \\
\hline Benthic Barrier & $\begin{array}{l}\text { Use natural or } \\
\text { synthetic materials } \\
\text { to cover plants }\end{array}$ & $\begin{array}{l}\text { Direct and } \\
\text { effective, may last } \\
\text { several seasons }\end{array}$ & $\begin{array}{l}\text { Expensive and } \\
\text { small-scale, } \\
\text { nonselective }\end{array}$ & $\begin{array}{l}\text { Around docks, } \\
\text { boat launches, } \\
\text { swimming areas, } \\
\text { and other small, } \\
\text { intensive use } \\
\text { areas }\end{array}$ & $\begin{array}{l}\text { Nonselective, } \\
\text { plant mortality } \\
\text { within one month } \\
\text { underneath barrier }\end{array}$ \\
\hline $\begin{array}{l}\text { Shading/Light } \\
\text { Attenuation }\end{array}$ & $\begin{array}{l}\text { Reduce light levels } \\
\text { by one of several } \\
\text { means: dyes, } \\
\text { shade cloth, plant } \\
\text { trees (rivers) }\end{array}$ & $\begin{array}{l}\text { Generally } \\
\text { inexpensive, } \\
\text { effective }\end{array}$ & $\begin{array}{l}\text { Nonselective, } \\
\text { controls all plants, } \\
\text { may not be } \\
\text { aesthetically } \\
\text { pleasing }\end{array}$ & $\begin{array}{l}\text { Smaller ponds, } \\
\text { man-made } \\
\text { waterbodies, small } \\
\text { streams }\end{array}$ & $\begin{array}{l}\text { Nonselective, but } \\
\text { may be long-term }\end{array}$ \\
\hline $\begin{array}{l}\text { Nutrient } \\
\text { Inactivation }\end{array}$ & $\begin{array}{l}\text { Inactivate } \\
\text { phosphorus (in } \\
\text { particular) using } \\
\text { alum }\end{array}$ & $\begin{array}{l}\text { Theoretically } \\
\text { possible }\end{array}$ & $\begin{array}{l}\text { Impractical for } \\
\text { rooted plants } \\
\text { limited by nitrogen }\end{array}$ & $\begin{array}{l}\text { Most useful for } \\
\text { controlling } \\
\text { phytoplankton by } \\
\text { inactivating water } \\
\text { column P }\end{array}$ & Variable \\
\hline
\end{tabular}

\section{Drawdown}

Drawdown is another effective aquatic plant management technique that alters the plant's environment. Essentially, the water body has all of the water removed to a given depth. It is best if this depth includes the entire depth range of the target species. Drawdown, to be effective, needs to be at least 1 month long to ensure thorough drying (Cooke 1980b). In northern areas, a drawdown in the winter that will ensure freezing of sediments is also effective. Although drawdown may be effective for control of hydrilla for 1 to 2 years (Ludlow 1995), it is most commonly applied to Eurasian watermilfoil (Siver et al. 1986) and other milfoils or submersed evergreen perennials (Tarver 1980). Drawdown requires that there be a mechanism to lower water levels. Although it is inexpensive and has long-term effects ( 2 or more years), it also has significant environmental effects and may interfere with use and intended function (e.g., power generation or drinking water supply) of the water body during the drawdown period. Lastly, species respond in very different manners to drawdown and often not in a 
consistent fashion (Cooke 1980b). Drawdown may provide an opportunity for the spread of highly weedy or adventive species, particularly annuals.

\section{Benthic barriers}

Benthic barriers or other bottom-covering approaches are another physical management technique that has been in use for a substantial period of time. The basic idea is that the plants are covered over with a layer of a growth-inhibiting substance. Many materials have been used, including sheets or screens of organic, inorganic, and synthetic materials; sediments such as dredge sediment, sand, silt or clay; fly ash; and combinations of the above (Cooke 1980a). The problem with using sediments is that new plants establish on top of the added layer (Engel and Nichols 1984). The problem with synthetic sheeting is that the gasses evolved from decomposition of plants and normal decomposition activities of the sediments underneath the barrier collect under the barrier, lifting it (Gunnison and Barko 1992). Benthic barriers will typically kill plants under them within 1 to 2 months, after which they may be removed (Engel 1984). Sheet color is relatively unimportant; opaque (particularly black) barriers work best, but even clear plastic barriers will work effectively (Carter et al. 1994). Sites from which barriers are removed will be rapidly recolonized (Eichler et al. 1995). In addition, synthetic barriers may be left in place for multiyear control but will eventually become sediment-covered and will allow colonization by plants. Benthic barriers, effective and fairly low cost control techniques for limited areas (e.g., $<1$ acre), may be best suited to high-intensity use areas such as docks, boat launch areas, and swimming areas. However, they are too expensive to use over widespread areas, and heavily affect benthic communities.

\section{Shading or light attenuation}

A basic environmental manipulation for plant control is light reduction or attenuation. This, in fact, may have been the first physical control technique. Shading has been achieved by fertilization to produce algal growth, application of natural or synthetic dyes, shading fabric, or covers, and establishing shade trees (Dawson 1986; Dawson and Kern-Hansen 1978; Madsen et al. 1999). During natural or cultural eutrophication, phytoplankton growth alone can shade macrophytes (Jones et al. 1983). Although light manipulation techniques may be useful for narrow streams or small ponds, in general these techniques are of only limited applicability.

\section{Nutrient inactivation}

The final physical management method often discussed is nutrient inactivation. Nutrient inactivation is commonly done for algal or phytoplankton control by adding alum to the water column, which binds phosphorus and thus limits the growth of algae (McComas 1993). However, larger vascular aquatic plants are typically limited by nitrogen rather than phosphorus and derive most of their nutrients from the sediment rather than from the water column. No chemical is available that binds nitrogen as readily as alum binds phosphorus. Additionally, the difficulties of adding a binding agent to the sediment rather than to the water 
column are obvious. Despite these limitations, nutrient inactivation has been attempted, but with limited success (Mesner and Narf 1987). At this point, nutrient inactivation for control of aquatic vascular plants is still in the research and development phase. 


\section{No Action}

While doing nothing is not, on the face of it, a management technique, the "no-action" alternative is one often used as the "baseline condition" for permits or environmental impact comparisons. "No action" is also the default choice of regulators and managers everywhere. Who can blame them? The direst of bureaucratic punishments is reserved for those who try and fail, while those who do nothing are rarely even reprimanded, much less punished.

When the various management techniques are evaluated (Figure 8), the assumption is erroneously made that doing nothing is environmentally neutral. In dealing with nonnative species like hydrilla, giant salvinia, and Eurasian watermilfoil, the environmental consequences of doing nothing may be high, possibly even higher than any of the effects of management techniques. Unmanaged, these species can have severe negative effects on water quality; native plant distribution, abundance, and diversity; and the abundance and diversity of aquatic insects and fish (Madsen 1997). Nonindigenous aquatic plants are the problem, and the management techniques are the collective solution. Nonnative plants are a biological pollutant that increases geometrically, a pollutant with a very long residence time and the potential to "biomagnify" in lakes, rivers, and wetlands.

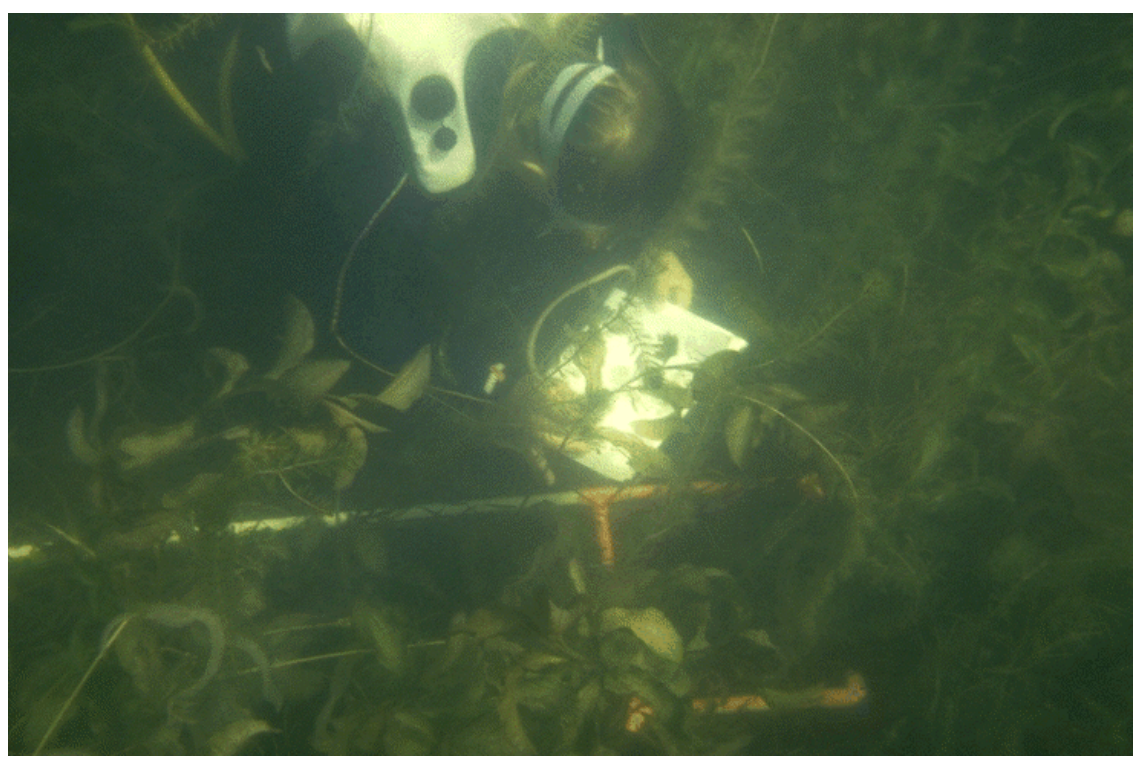

Figure 8. Author performing a quantitative evaluation of a plant community using underwater quadrats (photo by Dr. David L. Smith, Department of Biology, Le Moyne College, Syracuse, NY) 


\section{Conclusion}

Despite the views of some, there is no single cure-all solution to aquatic plant problems, no single "best choice." For that matter, several of these techniques can be made to work for most aquatic plant problems, given enough time and money. None of these techniques are evil or inherently unacceptable; likewise, none of these techniques are without flaws or potential environmental impacts. Rather, it is up to each management group to select the most appropriate techniques for their situation given a set of social, political, economic, and environmental conditions (Figure 9).

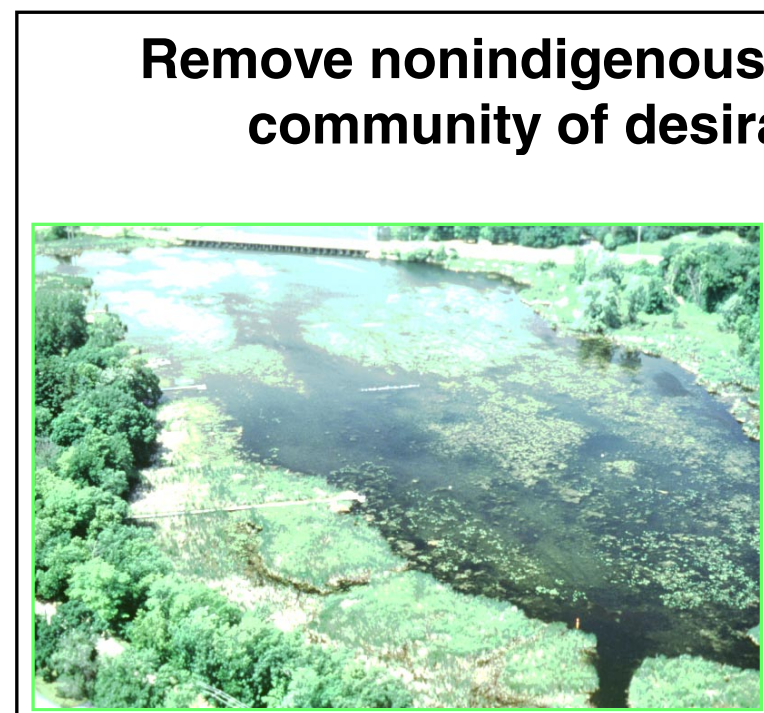

Carsons Bav, MN before treatment

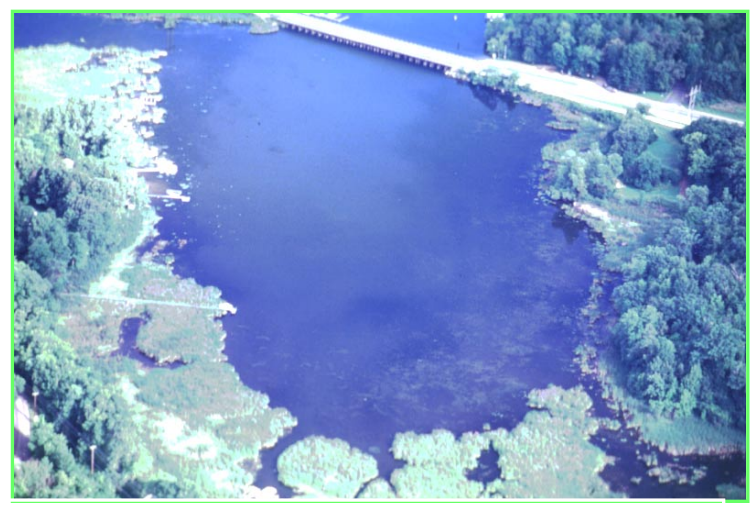

Carsons Bav, MN after treatment

Figure 9. Aquatic plant restoration goal 


\section{References}

Bonar, S. A., Vecht, S. A., Bennett, C. R., Pauley, G. B., and Thomas, G. L. (1993). Capture of grass carp from vegetated lakes. Journal of Aquatic Plant Management 31, 168-174.

Boyd, W. A., and Stewart, R. M. (1994). Status of Hydrellia pakistanae modeling efforts and approach for future development of the insect simulation. In: Proceedings, 28th Annual Meeting of the Aquatic Plant Control Research Program, 15-18 November 1993, Baltimore Maryland, Miscellaneous Paper A94-2, U.S. Army Engineer Waterways Experiment Station, Vicksburg, Mississippi. 53-57.

Buckingham, G. R. (1995). Foreign surveys and quarantine studies for biocontrol of Eurasian watermilfoil and hydrilla. In: Proceedings, 29th Annual Meeting of the Aquatic Plant Control Research Program, 14-17 November 1994, Vicksburg, Mississippi, Miscellaneous Paper A-95-3, U.S. Army Engineer Waterways Experiment Station, Vicksburg, Mississippi.

Buckingham, G.R., and Okrah, E. A. (1993). Biological and host range studies with two species of Hydrellia (Diptera: Ephydridae) that feed on hydrilla. Technical Report A-93-7, U.S. Army Engineer Waterways Experiment Station, Vicksburg, Mississippi.

Carpenter, S.R., and Adams, M. S. (1976). The macrophyte tissue nutrient pool of a hardwater eutrophic lake: Implications for macrophyte harvesting. Aquatic Botany 3, 239-255.

Carpenter, S. R., and Adams, M. S. (1978). Macrophyte control by harvesting and herbicides: Implications for phosphorus cycling in Lake Wingra, Wisconsin. Journal of Aquatic Plant Management 16, 20-23.

Carpenter, S. R., and Gasith, A. (1978). Mechanical cutting of submersed macrophytes: Immediate effects on littoral chemistry and metabolism. Water Research 12, 55-57.

Carter, D. R., Carter, S., and Allen, J. L. (1994). Submerged macrophyte control using plastic blankets. Water Science and Technology 29, 119-126. 
Cofrancesco, A. F., Jr. (1994). Biological control technology overview - Fiscal year 1993. In: Proceedings, 28th Annual Meeting of the Aquatic Plant Control Research Program, 15-18 November 1993, Baltimore Maryland, Miscellaneous Paper A-94-2, U.S. Army Engineer Waterways Experiment Station, Vicksburg, Mississippi.

Conyers, D. L., and Cooke, G. D. (1983). A comparison of the costs of harvesting and herbicides and their effectiveness in nutrient removal and control of macrophyte biomass. In: Lake Restoration, Protection and Management. U.S. Environmental Protection Agency, EPA 440/5-83-001, Washington, District of Columbia. 317-321.

Cooke, G. D. (1980a). Covering bottom sediments as a lake restoration technique. Water Resources Bulletin 16, 921-926. . (1980b). Lake level drawdown as a macrophyte control technique. Water Resources Bulletin 16, 317-322.

Creed, R. P., Jr., and Sheldon, S. P. (1993). The effect of the weevil Euhrychiopsis lecontei on Eurasian watermilfoil: Results from Brownington Pond and North Brook Pond. In: Proceedings, 27th Annual Meeting, Aquatic Plant Control Research Program, 16-19 November 1992, Bellevue, Washington. Miscellaneous Paper A-93-2, U.S. Army Engineer Waterways Experiment Station, Vicksburg, Mississippi. 99-117.

Creed, R. P., Jr., and Sheldon, S. P. (1994). The effect of two herbivorous insect larvae on Eurasian watermilfoil. Journal of Aquatic Plant Management 32, 21-26.

Creed, R. P., Jr., Sheldon, S. P., and Cheek, D. M. (1992). The effect of herbivore feeding on the buoyancy of Eurasian watermilfoil. Journal of Aquatic Plant Management 30, 75-76.

Dawson, F. H. (1986). Light reduction techniques for aquatic plant control. Lake and Reservoir Management 2, 258-262.

Dawson, F. H., and Kern-Hansen, U. (1978). Aquatic weed management in natural streams: The effect of shade by the marginal vegetation. Verhandlungen Internationale Vereinigung fur Theoretische und Angewandte Limnologie 20, 1451-1456.

Deschenes, P., and Ludlow, J. (1993). Maintenance control of hydrilla in the Winter Park Chain of Lakes, Florida. Aquatics 15(2), 13-15.

Durocher, P. P. (1994). Status of the grass carp program in Texas. In: Proceedings of the Grass Carp Symposium, 7-9 March 1994, Gainesville, Florida. U.S. Army Engineer Waterways Experiment Station, Vicksburg, Mississippi. 16-17. 
Eggeman, D. (1994). Integrated hydrilla management plan utilizing herbicides and triploid grass carp in Lake Istokpoga. In: Proceedings of the Grass Carp Symposium, 7-9 March 1994, Gainesville, Florida. U.S. Army Engineer Waterways Experiment Station, Vicksburg, Mississippi. 164-165.

Eichler, L. W., Bombard, R. T., Jr., Sutherland, J. W., and Boylen, C. W. (1993). Suction harvesting of Eurasian watermilfoil and its effect on native plant communities. Journal of Aquatic Plant Management 31, 144-148.

(1995). Recolonization of the littoral zone by macrophytes following the removal of benthic barrier material. Journal of Aquatic Plant Management 33, $51-54$.

Engel, S. (1984). Evaluating stationary blankets and removable screens for macrophyte control in lakes. Journal of Aquatic Plant Management 22, 43-48.

. (1990). Ecological impacts of harvesting macrophytes in Halverson Lake, Wisconsin. Journal of Aquatic Plant Management 28, 41-45.

Engel, S., and Nichols, S. A. (1984). Lake sediment alteration for macrophyte control. Journal of Aquatic Plant Management 22, 38-41.

Fowler, M. C., and Robson, T. O. (1978). The effects of food preferences and stocking rates of grass carp (Ctenopharyngodon idella Val.) on mixed plant communities. Aquatic Botany 5, 261-272.

Gallagher, J. E., and Haller, W. T. (1990). History and development of aquatic weed control in the United States. Reviews of Weed Science 5, 115-192.

Getsinger, K. D. (1991). Chemical control technology: History and overview. In: Proceedings, 25th Annual Meeting, Aquatic Plant Control Research Program, 26-30 November 1990, Orlando, Florida. Miscellaneous Paper A91-3, U.S. Army Engineer Waterways Experiment Station, Vicksburg, Mississippi. 197-200.

(1998). Chemical control research in the Corps of Engineers. J. Aquat. Plant Manage. 36, 61-64.

Getsinger, K. D., Dick, G. O., Crouch, R. M., and Nelson, L. S. (1994). Mesocosm evaluation of bensulfuron methyl activity on Eurasian watermilfoil, vallisneria, and American pondweed. Journal of Aquatic Plant Management $32,1-6$.

Getsinger, K. D., Hanlon, C., Joyce, J. C., Fox, A. M., and Haller, W. T. (1991). Herbicide application technique development for flowing water: Relationship of water exchange and submersed application methods. In: Proceedings, 25th Annual Meeting, Aquatic Plant Control Research Program, 26-30 November 1990, Orlando, Florida. Miscellaneous Paper A-91-3, U.S. Army Engineer Waterways Experiment Station, Vicksburg, Mississippi. 210-218. 
Getsinger, K. D., Turner, E. G., Madsen, J. D., and Netherland, M. D. (1997). Restoring native vegetation in a Eurasian water milfoil-dominated plant community using the herbicide triclopyr. Regulated Rivers: Research and Management 13, 357-375.

Gibbons, M. V., and Gibbons, H. L., Jr. (1988). Efficacy of rotovation in controlling Eurasian watermilfoil in the Pend Oreille River, Washington. Lake and Reservoir Management 4, 153-160.

Grodowitz, M. J., Center, T. D., and Snoddy, E. (1995). Current status on the use of insect biocontrol agents for the management of hydrilla. In:

Proceedings, 29th Annual Meeting of the Aquatic Plant Control Research Program, 14-17 November 1994, Vicksburg, Mississippi, Miscellaneous Paper A-95-3, U.S. Army Engineer Waterways Experiment Station, Vicksburg, Mississippi. 134-141.

Gunnison, G., and Barko, J. W. (1992). Factors influencing gas evolution beneath a benthic barrier. Journal of Aquatic Plant Management 30, 23-28.

Haag, K. H., and Habeck, D. H. (1991). Enhanced biological control of waterhyacinth following limited herbicide application. Journal of Aquatic Plant Management 29, 24-28.

Haller, W. T. (1994). Probable grass carp stocking scenarios. In: Proceedings of the Grass Carp Symposium, 7-9 March 1994, Gainesville, Florida. U.S. Army Engineer Waterways Experiment Station, Vicksburg, Mississippi. 236-238.

Haller, W. T., Fox, A. M., and Hanlon, C. A. (1992). Inhibition of hydrilla tuber formation by bensulfuron methyl. Journal of Aquatic Plant Management 30, $48-49$.

Harvey, J. L., Varley, D. R., and Evans, H. C. (1995). European surveys for pathogens of Eurasian watermilfoil. In: Proceedings, 29th Annual Meeting of the Aquatic Plant Control Research Program, 14-17 November 1994, Vicksburg, Mississippi, Miscellaneous Paper A-95-3, U.S. Army Engineer Waterways Experiment Station, Vicksburg, Mississippi. 130-133.

Helsel, D. (2000). "Planning for aquatic plant management and protection," LakeLine 20(1), 16-21 (Spring 2000).

Jones, R. C., Walti, K., and Adams, M. S. (1983). Phytoplankton as a factor in the decline of the submersed macrophyte Myriophyllum spicatum L. in Lake Wingra, Wisconsin, U.S.A. Hydrobiologia 107, 213-219.

Joyce, J. C. (1991). Future of chemical technology in aquatic plant management operations. In: Proceedings, 25th Annual Meeting, Aquatic Plant Control Research Program, 26-30 November 1990, Orlando, Florida. Miscellaneous Paper A-91-3, U.S. Army Engineer Waterways Experiment Station, Vicksburg, Mississippi. 240-244. 
Kangasniemi, B. J. (1983). Observations on herbivorous insects that feed on Myriophyllum spicatum in British Columbia. In: Proceedings, Second Annual Conference of the North American Lake Management Society, 26-29 October 1982, Vancouver, British Columbia. U.S. Environmental Protection Agency, EPA 440/5-83-001, Washington, District of Columbia. 214-218.

Kimbel, J. C., and Carpenter, S. R. (1981). Effects of mechanical harvesting on Myriophyllum spicatum $\mathrm{L}$. regrowth and carbohydrate allocation to roots and shoots. Aquatic Botany 11, 121-127.

Ludlow, J. (1995). Management of aquatic plant communities in Rodman reservoir from 1969-1994. Aquatics 17(3), 11-15.

Madsen, J. D. (1997). Methods for management of nonindigenous aquatic plants. In: J.O. Luken and J.W. Thieret, eds. Assessment and Management of Plant Invasions. Springer, New York. 145-171.

Madsen, J. D., Adams, M. S., and Ruffier, P. (1988). Harvest as a control for sago pondweed (Potamogeton pectinatus L.) in Badfish Creek, Wisconsin: Frequency, efficiency and its impact on stream community oxygen metabolism. Journal of Aquatic Plant Management 26, 20-25.

Madsen, J. D., Getsinger, K. D., Stewart, R. M., Skogerboe, J. G., Honnell, D. R., and Owens, C. S. (1999). Evaluation of transparency and light attenuation by Aquashade $^{\mathrm{TM}}$. Lake and Reservoir Management 15, 142-147.

Madsen, J. D., Sutherland, J. W., Bloomfield, J. A., Eichler, L. W., and Boylen, C. W. (1991). The decline of native vegetation under dense Eurasian watermilfoil canopies. Journal of Aquatic Plant Management 29, 94-99.

McComas, S. (1993). LakeSmarts: The first lake maintenance handbook. Terrene Institute, Washington District of Columbia.

Mesner, N., and Narf, R. (1987). Alum injection into sediments for phosphorus inactivation and macrophyte control. Lake and Reservoir Management 3, 256265.

Nelson, L. S., Shearer, J. F., and Netherland, M. D. (1998). Mesocosm evaluation of integrated fluridone-fungal pathogen treatment on four submersed plants. J. Aquat. Plant Manage. 36, 73-77.

Nesheim, O. N. (1993). Understanding pesticide regulation-new pesticide registration. Aquatics 15(4), 19-20.

Netherland, M. D. (1991). Herbicide concentration/exposure time relationships for Eurasian watermilfoil and hydrilla. In: Proceedings, 25th Annual Meeting, Aquatic Plant Control Research Program, 26-30 November 1990, Orlando, Florida. Miscellaneous Paper A-91-3, U.S. Army Engineer Waterways Experiment Station, Vicksburg, Mississippi. 205-209. 
Netherland, M. D., Getsinger, K. D., and Skogerboe, J. D. (1997). Mesocosm evaluation of the species-selective potential of fluridone. J. Aquat. Plant Manage. 35, 41-50.

New York State Department of Environmental Conservation (NYSDEC) and Federation of Lake Associations, Inc. (FOLA). (1990). Diet for a small lake: A New Yorker's guide to lake management. New York State Department of Environmental Conservation, Albany, New York.

Newman, R. M., and Maher, L. M. (1995). New records and distribution of aquatic insect herbivores of watermilfoils (Haloragaceae: Myriophyllum spp.) in Minnesota. Entomological News 106, 6-12.

Newman, R. M., Holmberg, K. L., Biesboer, D. D., and Penner, B. G. (1996). Effects of the potential biological control agent, Euhrychiopsis lecontei, on Eurasian watermilfoil in experimental tanks. Aquatic Botany 53, 131-150.

Nichols, S. A. (1984). Macrophyte community dynamics in a dredged Wisconsin lake. Water Resources Bulletin 20, 573-576.

Nichols, S. A. (1991). The interaction between biology and the management of aquatic macrophytes. Aquatic Botany 41, 225-252.

Nichols, S., and Cottam, G. (1972). Harvesting as a control for aquatic plants. Water Resources Bulletin 8, 1205-1210.

Peterson, S. A. (1982). Lake restoration by sediment removal. Water Resources Bulletin 18, 423-435.

Peterson, S. A., Smith, W. L., and Malueg, K. W. (1974). Full-scale harvest of aquatic plants: Nutrient removal from a eutrophic lake. Journal of the Water Pollution Control Federation 46, 697-707.

Pine, R. T., and Anderson, L. W. J. (1991). Plant preferences of triploid grass carp. Journal of Aquatic Plant Management 29, 80-82.

Shearer, J. F. (1995). The use of pathogens for the management of hydrilla and Eurasian watermilfoil. In: Proceedings, 29th Annual Meeting of the Aquatic Plant Control Research Program, 14-17 November 1994, Vicksburg, Mississippi, Miscellaneous Paper A-95-3, U.S. Army Engineer Waterways Experiment Station, Vicksburg, Mississippi. 124-129.

Siver, P. A., Coleman, A. M., Benson, G. A., and Simpson, J. T. (1986). The effects of winter drawdown on macrophytes in Candlewood Lake, Connecticut. Lake and Reservoir Management 2, 69-73.

Smart, R. M., and Doyle, R. (1995). Ecological theory and the management of submersed plant communities. Information Exchange Bulletin A-95-3, U.S. Army Engineer Waterways Experiment Station, Vicksburg, Mississippi. 
Smart, R. M., Doyle, R. D., Madsen, J. D., and Dick, G. O. (1996a). Establishing native submersed aquatic plant communities for fish habitat. Amer. Fish. Soc. Symp. 16, 347-356.

. (1996b). Establishing native submersed aquatic plant communities in southern reservoirs. Technical Report A-96-2, U.S. Army Engineer Waterways Experiment Station, Vicksburg, Mississippi.

Sorsa, K. K., Nordheim, E. V., and Andrews, J. H. (1988). Integrated control of Eurasian water milfoil, Myriophyllum, by a fungal pathogen and a herbicide. Journal of Aquatic Plant Management 26, 12-17.

Stanley, J. G., Miley, W. W., and Sutton, D. L. (1978). Reproductive requirements and likelihood for naturalization of escaped grass carp in the United States. Transactions of the American Fisheries Society 107, 119-128.

Stewart, R. M., and Boyd, W. A. (1994). Simulation model evaluation of sources of variability in grass carp stocking requirements. In: Proceedings of the Grass Carp Symposium, 7-9 March 1994, Gainesville, Florida. U.S. Army Engineer Waterways Experiment Station, Vicksburg, Mississippi. 85-92.

Tarver, D. P. (1980). Water fluctuation and the aquatic flora of Lake Miccosukee. Journal of Aquatic Plant Management 18, 19-23.

Tobiessen, P., Swart, J., and Benjamin, S. (1992). Dredging to control curly-leaf pondweed: A decade later. Journal of Aquatic Plant Management 30, 71-72.

Van, T. K. (1988). Integrated control of waterhyacinth with Neochetina and paclobutrazol. Journal of Aquatic Plant Management 26, 59-61.

Van Dyke, J. M., Leslie, A. J., Jr., and Nall, L. E. (1984). The effects of the grass carp on the aquatic macrophytes of four Florida lakes. Journal of Aquatic Plant Management 22, 87-95.

Webb, M. A., Elder, H. S., and Howells, R. G. (1994). Grass carp reproduction in the lower Trinity River, Texas. In: Proceedings of the Grass Carp Symposium, 7-9 March 1994, Gainesville, Florida. U.S. Army Engineer Waterways Experiment Station, Vicksburg, Mississippi. 29-32.

Westerdahl, H. E., and Getsinger, K. D. (1988a). Aquatic plant identification and herbicide use guide. Volume I. Aquatic herbicides and application equipment. Technical Report A-88-9, U.S. Army Engineer Waterways Experiment Station, Vicksburg, Mississippi.

. 1988b. Aquatic plant identification and herbicide use guide.

Volume II. Aquatic plants and susceptibility to herbicides. Technical Report A-88-9, U.S. Army Engineer Waterways Experiment Station, Vicksburg, Mississippi. 
Wile, I. (1975). Lake restoration through mechanical harvesting of aquatic vegetation. Verhandlungen Internationale Vereinigung fur Theoretische und Angewandte Limnologie 19, 660-671. 
Public reporting burden for this collection of information is estimated to average 1 hour per response, including the time for reviewing instructions, searching existing data sources, gathering and maintaining the data needed, and completing and reviewing the collection of information. Send comments regarding this burden estimate or any other aspect of this collection of information, including suggestions for reducing this burden, to Washington Headquarters Services, Directorate for Information Operations and Reports, 1215 Jefferson Davis Highway, Suite 1204, Arlington, VA 22202-4302, and to the Office of Management and Budget, Paperwork Reduction Project (0704-0188), Washington, DC 20503.
1. AGENCY USE ONLY (Leave blank)
2. REPORT DATE
September 2000
3. REPORT TYPE AND DATES COVERED
Final report

4. TITLE AND SUBTITLE

5. FUNDING NUMBERS

Advantages and Disadvantages of Aquatic Plant Management Techniques

6. AUTHOR(S)

John D. Madsen

7. PERFORMING ORGANIZATION NAME(S) AND ADDRESS(ES)

U.S. Army Engineer Research and Development Center

Environmental Laboratory

3909 Halls Ferry Road, Vicksburg, MS 39180-6199

8. PERFORMING ORGANIZATION REPORT NUMBER

ERDC/EL MP-00-1

9. SPONSORING/MONITORING AGENCY NAME(S) AND ADDRESS(ES)

10. SPONSORING/MONITORING

U.S. Army Corps of Engineers, Washington, DC 20314-1000; AGENCY REPORT NUMBER

Aquatic Ecosystem Restoration Foundation

817 Pepperwood Drive, Lansing, MI 48917-4048

11. SUPPLEMENTARY NOTES

12a. DISTRIBUTION/AVAILABILITY STATEMENT

12b. DISTRIBUTION CODE

Approved for public release; distribution is unlimited

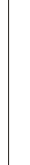

13. ABSTRACT (Maximum 200 words)

This report provides an overview of the environmental and practical advantages and disadvantages of the major aquatic plant management methods, including biological, chemical, mechanical, and physical control techniques.

14. SUBJECT TERMS

Aquatic plant control

Herbicides

15. NUMBER OF PAGES

Biological control

Mechanical control

Chemical control

Physical control

16. PRICE CODE

17. SECURITY CLASSIFICATION OF REPORT UNCLASSIFIED
18. SECURITY CLASSIFICATION OF THIS PAGE UNCLASSIFIED
19. SECURITY CLASSIFICATION OF ABSTRACT 